\title{
Research Square \\ Observations on the Biology and Structure of Three Dry Tropical Forests in South India
}

O.K. Remadevi ( $\square$ okremadevi@gmail.com )

Research

Keywords: Tropical Dry Forest, Individual Structure, Forest Biology, long-term observational studies

Posted Date: August 11th, 2020

DOI: https://doi.org/10.21203/rs.3.rs-56368/v1

License: (9) (i) This work is licensed under a Creative Commons Attribution 4.0 International License. Read Full License 


\title{
Observations on the Biology and Structure of three Dry Tropical Forests in South India
}

\author{
Remadevi O.K ${ }^{1 *}$, M. Manjunatha ${ }^{1}$, Balasubramanya Sharma ${ }^{1}$, B. Saritha ${ }^{1}$, Poorvashree ${ }^{1}$, H.S Suresh ${ }^{2}$, K.H. \\ Vinaya Kumar ${ }^{1}$, Ritu Kakkar ${ }^{1}$, R.K. Singh ${ }^{1}$ and Klaus v.Gadow ${ }^{3,4}$. \\ Author afiliations: ${ }^{1}$ Environmental Management and Policy Research Institute, "Hasiru Bhavana”, Doresanipalya Forest Campus, Vinayaka \\ Nagara Circle, JP Nagar 5th Phase, Bangalore 560 078, India; ${ }^{2}$ Center for Ecological Sciences, Indian Institute of Science, Bengaluru; ${ }^{3}$ Faculty \\ of Forestry and Forest Ecology, Georg-August-Universität, Göttingen, Germany; ${ }^{4}$ Department of Forestry and Wood Science, Faculty of \\ AgriSciences, Stellenbosch University, Matieland, South Africa. \\ *Corresponding author: Email: okremadevi@gmail.com; empri.climatechange@gmail.com
}

\section{Highlights:}

1. Three large permanent study areas with mapped trees, shrubs and climbers in species-rich tropical dry deciduous forests on the South Indian Deccan Plateau provide the empirical evidence for this study.

2. The study areas are located in close vicinity to each other, but differ in species composition, structure and human impact.

3. We present a descriptive section with details of the 130 woody plant species that were assessed, and a quantitative section with examples of new modeling approaches.

4. The results are of interest to scientists involved in studies of diverse forests, not only in South India, but also in other regions of the world.

\section{Abstract}

Tropical dry deciduous forests are found in variable climates characterized by low rainfall where woody plants possess several functional traits that permit them to endure severe water stress for several months of the year. We present an assessment of species-rich Dry Tropical Forests of the South Indian Deccan Plateau based on three large, tree-mapped field plots located in close vicinity to each other. The study includes a descriptive section (details of 130 woody plant species) and a modeling section. The modeling section presents specific species-area relations, species abundance distributions and relationships between biological attributes and individual-based structural attributes. The Monod equation is found most suitable for modeling the species-area relations confirming previous studies. The shape of the species abundance distribution follows the Weibull model which represents an alternative to the traditional lognormal model; the Weibull parameters are related linearly to species richness which is a new finding.

Keywords: Tropical Dry Forest; Individual Structure, Forest Biology. long-term observational studies. 


\section{Introduction}

Skilful and continuous observation provides essential evidence about dynamic processes in forest ecosystems (Sagarin and Pauchard, 2012). Examples of observational infrastructures are national forest inventories, field experiments and long-term observational studies. The objective of a national forest inventory is to prepare reports about the state of the forest resource at a given time and within a specific geographical context (Alekseev et al., 2019; Zeng et al., 2015). Field experiments are established to evaluate ecosystem response to specific treatments. Examples of manipulated field experiments include thinning and fertilizer treatments, short-rotation coppice trials and biodiversity-ecosystem functioning experiments. Forest observational studies complement forest inventories, and represent an important alternative to designed experiments (Condit, 2008). The system is not manipulated, trees are mapped, and field plots are large to capture effects of scale. Once established, re-measurements continue on the same site to assess the response to environmental change and human impact. A Forest Observational Study thus represents an important research infrastructure which provides a continuous flow of information about forest ecosystem response to disturbance and changing environmental conditions. More recently, such studies, established in natural and semi-natural forests in China, India, Africa and Mexico, have emerged as an important ecological infrastructure, complementing national forest inventories and designed experiments (Gadow et al., 2016). We present three examples of such studies established in the tropical dry deciduous forests of Southern India.

\subsection{Tropical Dry Deciduous Forests of India}

Forest classification systems were developed by experienced ecologists who were able to see differences and commonalities without getting bogged down by the dazzling variation in small-scale site conditions, community structures and species compositions. An example is the "official" forest classification system of India (Champion and Seth, 1968). The classification includes 14 forest types: Wet Evergreen forest, Semi Evergreen forest, Moist Deciduous forest, Dry Deciduous forest, Littoral, Swamp/Mangrove forest, Dry Evergreen forest, Thorn forest, Sub tropical broad leaved forest, Subtropical Pine forest, Subtropical Dry Evergreen forest, Montane Wet Temperate forest ${ }^{1}$.

Hui and Richardson (2017) have shown how humans have been rearranging the world's biota following the era of European colonization, and especially through the post-second World War globalization. Humans

\footnotetext{
${ }^{1}$ A more recent classification by Reddy et al. (2015) includes 16 forest types: the 14 types by Champion and Seth (1968) with a modified wording, plus the categories "Savannah" and "Plantations".
} 
have generated widespread biological invasions, leading to radical alterations to the functioning of ecosystems. Acacia species that are commercially important have been extensively planted in areas outside their natural range. Eucalypts have had modest invasive success despite their wide dissemination. Casuarinas have only recently been widely planted and little is known of their invasion ecology (Richardson et al., 2014). The primary forests of the world have not only been modified by human-mediated introductions of organisms to areas well outside their potential range; they have also been subject to extensive use and modification by unsustainable exploitation, illegal logging (Kleinschmit et al., 2016) or sophisticated "near-natural" management (Schütz et al., 2012). Marris (2013) proclaims such new ecosystems the "new normal" and calls on scientists and the public to embrace them and to "shake off the yoke of history".

Tropical dry deciduous forests are found in severe and extremely variable climates characterized by low rainfall and nutrient-poor soils where woody plants possess several functional traits that permit them to endure severe water stress for several months of the year. Canopy trees on drying soils typically respond to an extended drought by shedding their leaves (Borchert 1994). The lack of precipitation during several months of the year produces ecosystems that have adaptated to survive a prolonged dry season. Deciduousness is the single most important adaptation among plants to the extended droughts. According to Singh and Chaturvedi (2017), these forests are among the most vulnerable and fragmented ecosystems in the world. In India, tropical dry deciduous forests are widely distributed over a large area. The tropical dry deciduous forests of the South Indian Deccan Plateau are represented by a few protected remnants of very particular ecosystems within densely populated areas. Fig. 1 shows the distribution of forest types prepared by the Forest Survey of India, and based on the classification by Champion and Seth (1968). 


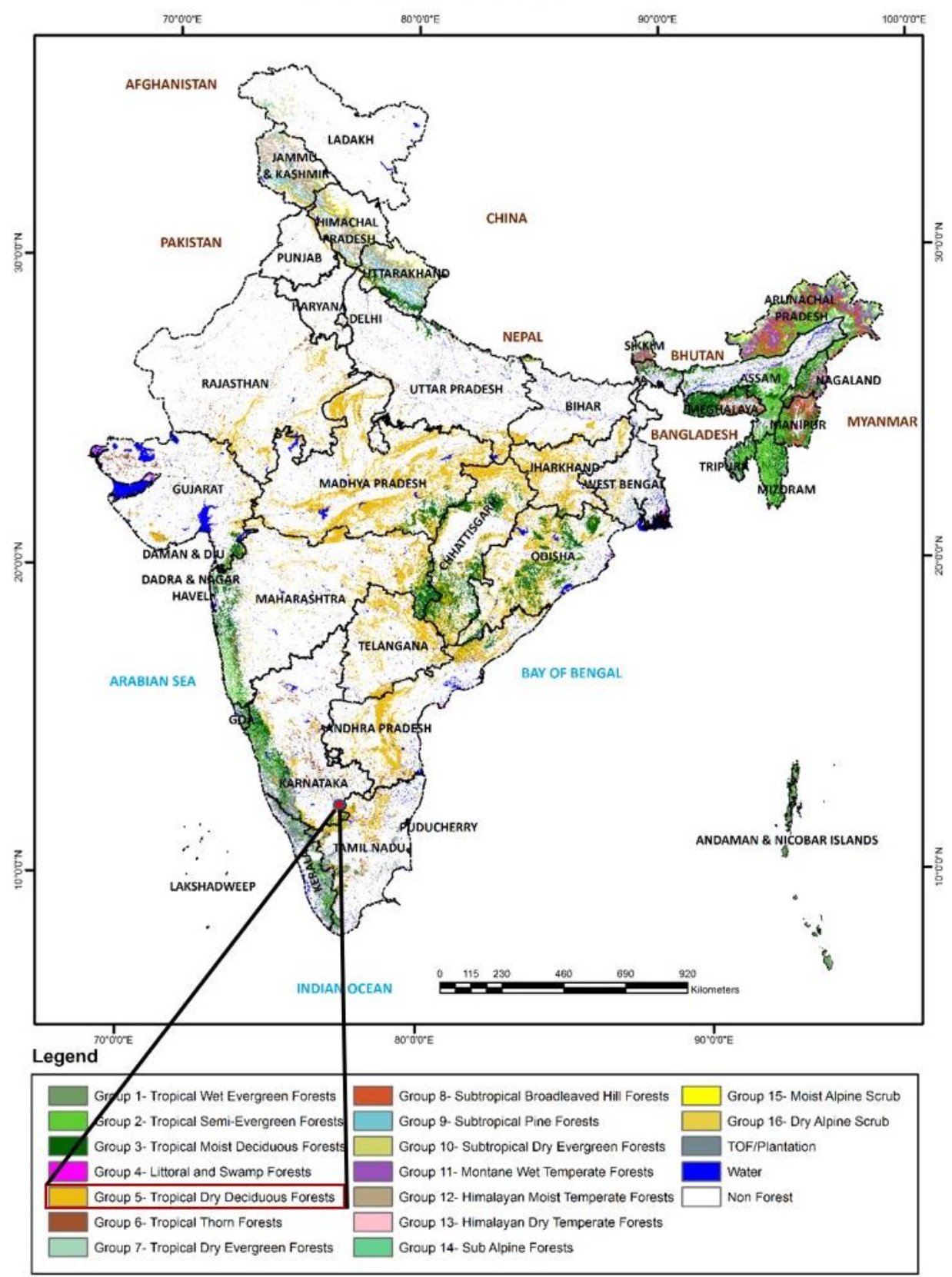

Figure 1. Distribution of forest types in India (map kindly provided by the Forest Survey of India, 2019). The study areas are located in the vicinity of Bengaluru in the South-Eastern part of the State of Karnataka.

Improved knowledge about the structure and dynamics of these forests, based on carefully selected observational field plots with mapped trees, will contribute to improved understanding and more effective conservation of this unique natural heritage. Three such protected areas, represent the empirical basis for this study. 


\subsection{Study Objectives}

Studies of small-scale structural patterns in forests are still relatively rare (Hui et al., 1998; Aguirre et al., 2003; Pommerening and Grabarnik, 2019). Accordingly, the objective of this study is to contribute to improved understanding of these unique ecosystems by analyzing their biology and structure in some detail. Particular objectives are: 1. to apply specific methods of structural analysis based on the attributes of neighborhoods in the vicinity of individual trees; 2. to study relationships between the relative frequency and mean size of individual trees and the structural pattern in their immediate neighborhood; 3. to assess the biological and structural differences among the three study areas by comparing the species-area relationships and species abundance distributions. We expect that our study will contribute to improved understanding of these communities, raise awareness among the scientific community, and thus contribute to more effective conservation of these unique forests in South India. The methodological approaches, described in the 'Methods' section, are applied to the observations collected. The results are discussed and compared with the results of similar studies in other regions of the world.

\section{Methods}

\subsection{Study Areas}

Three large protected field plots were established by the Environmental Management and Policy Research Institute (EMPRI) in Bengaluru. The plots are designated Bugarikallu (Bg), Thalewoodhouse (Tw) and Doresanipalya (Do). GPS coordinates and elevations are presented in Tab. 1.

Table 1. GPS coordinates and elevations of the four cornerpoints (1..4) of the Bugarikallu (Bg), Thalewoodhouse (Tw) and Doresanipalya (Do) study areas. The distances are shown in the table at right (6.07 km between Bg1 and Tw1); (14.6 km between Tw1 and Do1); $20.62 \mathrm{~km}$ between Bg1 and Do1).

\begin{tabular}{|c|c|c|c|c|c|c|c|}
\hline $\begin{array}{c}\text { Location } \\
\text { points }\end{array}$ & Latitude & Longitude & $\begin{array}{c}\text { Elevation } \\
\text { (m) }\end{array}$ & $\begin{array}{c}\text { Accuracy } \\
(+/ \text {-meters })\end{array}$ & \multicolumn{3}{|c|}{ Distance $(\mathrm{km})$} \\
\hline \multicolumn{5}{|c|}{ Bugarikallu plot } & \multirow{10}{*}{6.07} & & \multirow{15}{*}{20.65} \\
\hline Bg1 & $12^{0} 42^{\prime} 47.689^{\prime \prime} \mathrm{N}$ & $77^{0} 32^{\prime} 25.422^{\prime \prime} \mathrm{E}$ & 918.6 & 2.8 & & & \\
\hline Bg2 & $12^{0} 42^{\prime} 50.947^{\prime \prime} \mathrm{N}$ & $77^{0} 32^{\prime} 25.883^{\prime \prime} \mathrm{E}$ & 918.1 & 2.3 & & & \\
\hline Bg3 & $12^{0} 42^{\prime} 51.131 " \mathrm{~N}$ & $77^{0} 32^{\prime} 22.819^{\prime \prime} \mathrm{E}$ & 939 & 3.3 & & & \\
\hline Bg 4 & $12^{0} 42^{\prime} 47.988^{\prime \prime} \mathrm{N}$ & $77^{0} 32^{\prime} 22.063^{\prime \prime} \mathrm{E}$ & 926.4 & 4.3 & & & \\
\hline \multicolumn{5}{|c|}{ Thalewoodhouse plot } & & & \\
\hline Tw1 & $12^{0} 45^{\prime} 52.236^{\prime \prime} \mathrm{N}$ & $77^{0} 33^{\prime} 33.023^{\prime \prime} \mathrm{E}$ & 906.4 & 3.1 & & \multirow{9}{*}{14.61} & \\
\hline Tw2 & $12^{0} 45^{\prime} 52.157^{\prime \prime} \mathrm{N}$ & $77^{0} 33^{\prime} 36.515^{\prime \prime} \mathrm{E}$ & 936.4 & 6.3 & & & \\
\hline Tw3 & $12^{0} 45^{\prime} 48.312^{\prime \prime} \mathrm{N}$ & $77^{0} 33^{\prime} 36.205^{\prime \prime} \mathrm{E}$ & 912.6 & 5.4 & & & \\
\hline Tw4 & $12^{0} 45^{\prime} 49.097^{\prime \prime} \mathrm{N}$ & $77^{0} 33^{\prime} 33.210^{\prime \prime} \mathrm{E}$ & 906.7 & 5.1 & & & \\
\hline \multicolumn{5}{|c|}{ Doresanipalya plot } & & & \\
\hline Do1 & $12^{0} 53^{\prime} 32.525^{\prime \prime} \mathrm{N}$ & $77^{0} 35^{\prime} 26.520^{\prime \prime} \mathrm{E}$ & 918.9 & 9.6 & & & \\
\hline Do2 & $12^{0} 53^{\prime} 34.915^{\prime \prime} \mathrm{N}$ & $77^{0} 35^{\prime} 24.403^{\prime \prime} \mathrm{E}$ & 921.3 & 3.2 & & & \\
\hline Do3 & $12^{0} 53^{\prime} 37.118^{\prime \prime} \mathrm{N}$ & $77^{0} 35^{\prime} 26.876^{\prime \prime} \mathrm{E}$ & 920.4 & 8.6 & & & \\
\hline Do4 & $12^{0} 53^{\prime} 34.717^{\prime \prime} \mathrm{N}$ & $77^{0} 35^{\prime} 29.069^{\prime \prime} \mathrm{E}$ & 913.6 & 3.2 & & & \\
\hline
\end{tabular}


The three study areas, shown in Fig. 2 in relation to their immediate surroundings, enjoy a high degree of protection. Heavy rainfall occurs during the months of September and October from the North-east monsoon and torrential rains from June to August from the South-west monsoon. Annual rainfall (based on South-West monsoon, North-East monsoon and Pre-monsoon) varies between 417 and $1494 \mathrm{~mm}$ with a mean of $869 \mathrm{~mm}$ measured during the period 1960 to 2016; occasionally the area receives heavy cyclonic rains in October and November. The mean annual temperature is around $24.7^{\circ} \mathrm{C}$ with a maximum $39.4^{\circ} \mathrm{C}$ and a minimum of $10.2^{\circ} \mathrm{C}$. The soils have been classified as silty clay loam (Thalewoodhouse), sandy clay (Bugarikallu), and loamy sand/sandy loam (Doresanipalya). Detailed descriptions are presented by Raju (2014).

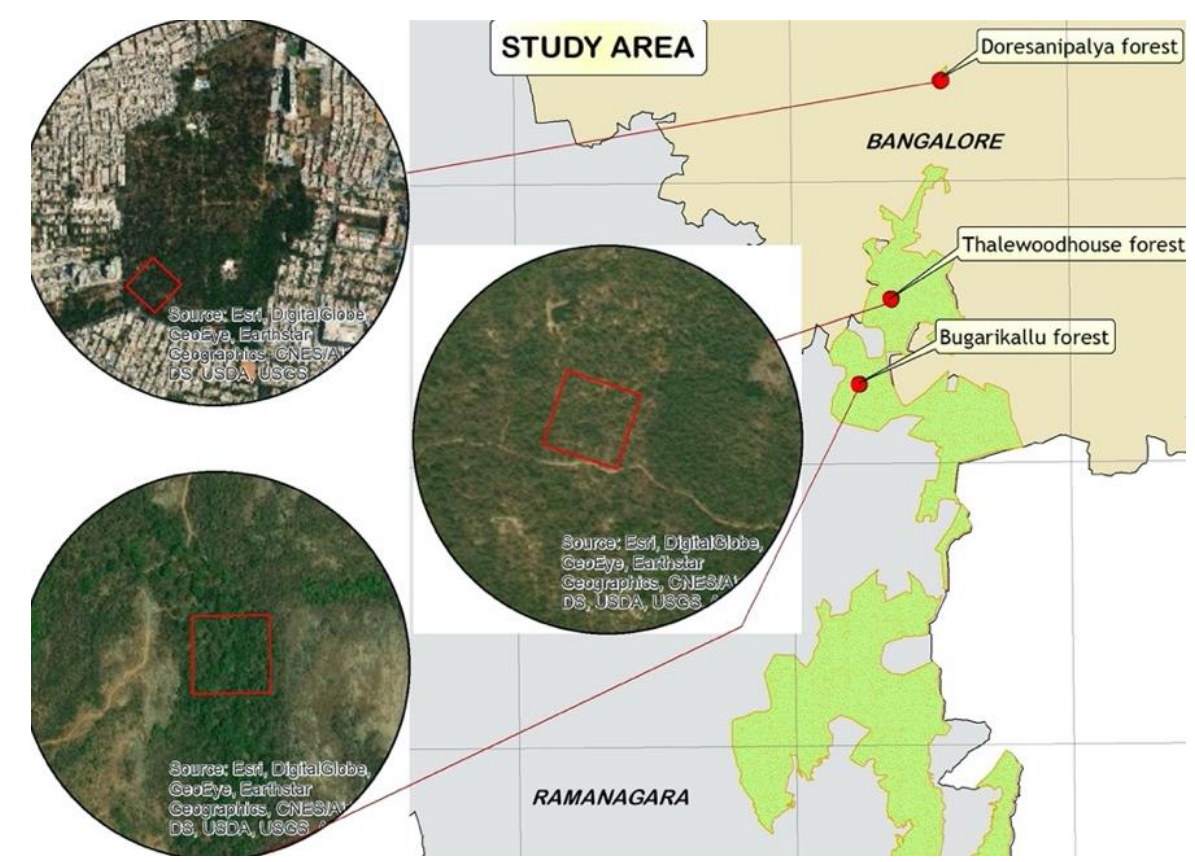

Figure 2. Location of the three study sites to the south of the Bengaluru city center. Google map images of the study sites and their immediate surroundings are shown in the three circles.

The Doresanipalya plot is surrounded by urban settlement with a high population density in the suburbs of the city of Bengaluru. Thalewoodhouse and Bugarikallu are located in the Bannerghatta National Park which is shown in green color in Fig. 2. All three sites are strictly protected, and located in close vicinity to each other (distances are shown in Tab. 1.).

\subsection{Descriptive Methods}

Descriptive details for each woody plant species will be developed, separately for each plot, including plant taxonomies, taxonomic ratios and number of introduced or invasive species. We will also present a brief 
summary of the 22 species of climbers encountered in the three study areas. The climbers are classified based on the mode of climbing as twiners, lianas and stragglers.

\subsection{Quantitative Methods}

\subsubsection{The Species-Area Relationship}

To allow comparisons of the study sites in terms of species richness, it is necessary to develop a relation between the contiguous plot area and the number of species in each plot. A number of models have been proposed to describe the species-area relation (Monod, 1950; de Caprariis et al.,1976; Gitay et al.,1991; Williams, 1995; Tjørve, 2003). Asymptotic functions are appropriate in very large plots where all species are likely to be captured by the samples. The power function is more suitable for small plot sizes where the maximum number of species is unknown. The following function, proposed by Monod (1950), represents a suitable compromise and will be used in our study to estimate the species-area relation:

$$
\mathrm{S}=\frac{a \cdot A}{1+b \cdot A}
$$

where $\mathrm{a}, \mathrm{b}$ are empirical parameters; $\mathrm{S}$ is number of species; $\mathrm{A}$ is a contiguous forest area $\left(\mathrm{m}^{2}\right)$. We derive such a species-area relation by assigning sample plots of increasing size to random positions within the study area. The sampled area and associated number of species are used to derive a species-area relation (SAR) for the whole plot. Eq. 1 has the following properies: 1) when $A=0$, then $S=0$; 2) $S$ increases with increasing $A$, until an asymptotic value $\left(S_{\max }\right)$ is reached; 3) the estimated maximum number of tree species equals $a / b$, which is a useful property.

\subsubsection{The Species-Abundance Distribution}

The species abundance distribution (SAD) describes the abundances of all species recorded within a forest community of interest. The SAD may explain processes of community assembly, and is believed to be one of the most ubiquitous patterns in ecology (Matthews and Whittaker, 2014). We estimate the SAD using the Weibull distribution:

$\mathrm{LN}=\mathrm{k} \cdot e^{(-S R / b)^{c}}$

where $\mathrm{LN}$ is the estimated logarithm of the number of individuals; $\mathrm{k}$ is the log (number of individuals of species 1, i.e. the species with the maximum number of individuals). SR is species rank; b and c are estimated parameters. 


\subsubsection{Forest Structure: cell-based}

Information about ecosystem structure presents a useful complement to the biological analysis of species richness and abundance patterns. A first approach to characterizing structure is to subdivide a study area into smaller cells (or quadrats). The subdivision into smaller spatial units facilitates detailed analysis of small scale patterns, as well as comparison among different study areas. Fig. 3 presents a visual impression of the spatial species mix and the tree size distribution in the three study areas. Some species are size-dominant represented by large individuals: Ficus benghalensis in Bugarikallu, Terminalia paniculata and Eucalyptus tereticornis in Doresanipalya, and Ficus microcarpa, Terminalia arjuna, Premna tomentosa, and Albizia odoratissima in Thalewoodhouse.

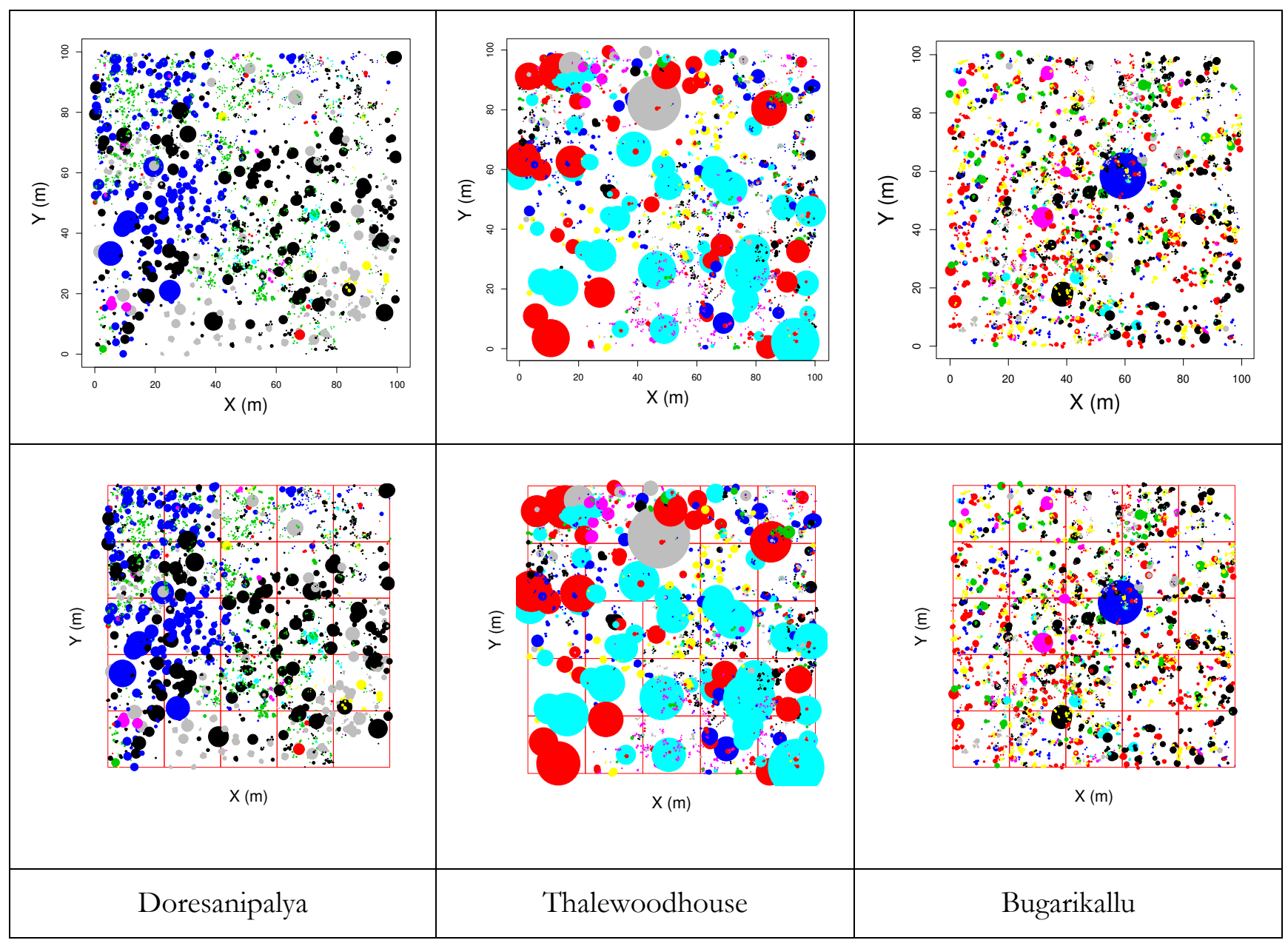

Figure 3. A general impression of the spatial species mix and tree size distribution in the three study areas. Each species has a unique color across all three study sites. The subdivision into smaller cells facilitates analysis of the spatial distribution (and scale dependence) of particular patterns.

The bottom row in Fig 3 shows a subdivision into smaller cells. We will analyze the cell-based distributions of the following seven variables in each study area: 

BA_ha: basal area in $\mathrm{m}^{2}$ per ha
N_ha: number of woody plants per ha
S: $\quad$ cell richness (number of species in cell)
Dq: $\quad$ quadratic mean dbh $(\mathrm{cm})$
CVD: $\quad$ dbh coefficient of variation
M: $\quad$ cell Mingling (the ratio number of species/number of individuals in cell)
CE: $\quad$ Clark \& Evans index in cells

The absolute discrepancy between the distributions of these variable in two study areas was calculated using the following criterion:

$$
d=\frac{1}{2} \sum_{i=1}^{m}\left|p_{i}-q_{i}\right|
$$

where $\mathrm{p}_{\mathrm{i}}$ and $\mathrm{q}_{\mathrm{i}}$ are the relative frequencies in the $i$ 'th frequency class of a particular variable in pairs of study areas that we wish to compare. The absolute discrepancy $d$ thus represents the proportion of a particular frequency in one study area that has to be changed such that both distributions (ordered by specific frquency classes) are identical. Our analysis is limited to 20 x $20 \mathrm{~m}$ cells.

\subsubsection{Forest Structure: Individual-based}

Forest structure may also be characterized by evaluating the immediate neighborhood of selected tree species. We will use the variables Mingling, Dominance and Size Differentiation to describe the specific neighborhood constellations of each individual species. Three measures of species-specific structural diversity are defined as follows (Gadow, 1993; c.f. Pommerening et al., 2020):

\begin{tabular}{|c|c|c|}
\hline Mingling (M) & Dominance (D) & Size Differentiation (T) \\
\hline $\begin{array}{l}\text { Mean heterospecific fraction of } \\
\text { trees among the } \mathrm{k} \text { nearest } \\
\text { neighbours of a given tree } \mathrm{i} \text {. }\end{array}$ & $\begin{array}{l}\text { Mean fraction of } n \text { nearest } \\
\text { neighbors with a } \mathrm{dbh}<(\mathrm{dbh} \text { of } \\
\text { the reference tree }) \text {. }\end{array}$ & $\begin{array}{l}\text { Mean of the ratio of smaller and } \\
\text { larger tree sizes } u \text { of the } \mathrm{k} \text { nearest } \\
\text { neighbours subtracted from one. }\end{array}$ \\
\hline $\begin{array}{r}M_{i}=\frac{1}{k} \sum_{j=1}^{k} 1 \text { species }_{i} \\
\left.\neq \text { species }_{j}\right)\end{array}$ & $D_{i}=\frac{1}{k} \sum_{j=1}^{k} 1\left(d b h_{i}>d b h_{j}\right)$ & $T_{i}=1-\frac{1}{k} \sum_{j=1}^{k} \frac{\min \left(u_{i}, u_{j}\right)}{\max \left(u_{i}, u_{j}\right)}$ \\
\hline
\end{tabular}


The three variables represent a system for characterizing structural patterns at high resolution in a consistent set where all the variables assume values in the interval [0,1]. Mingling defines the degree of spatial segregation of the tree species (Gadow 1993; Aguirre et al., 2003; Pommerening and Grabarnik, 2019). Dominance measures the size dominance of the reference tree in relation to its immediate surrounding (Hui et al., 1998). Size Differentiation measures the variation of tree sizes between the reference tree and its nearest neighbors (Pommerening et al., 2020). Instead of selecting a particular reference species (as was done in this study), we may wish to select all trees that belong to a particular family, or all dominant trees of a given species, as reference trees with the aim to study their particular neighborhoods.

Note that reference trees located close to the plot edge may produce a biased estimate of the neighborhood constellation because some of the real nearest neighbors may be located outside, beyond the plot perimeter. To avoid such bias, edge correction has to be employed. The simplest method involves a definition of a buffer around the plot edges. Edge correction, ensuring that the distance to the plot boundary of each reference tree must be greater than the distance to its 4th neighbor, is applied in this study to avoid biased estimates of the neighborhood parameters.

\section{Results}

We present descriptive and modeling results. The descriptive results are assumed to be of interest to biologists interested in taxonomic detail, while the modeling results allow comparisons among forest structure in a wider context.

\subsection{Descriptive Results}

\subsubsection{Woody Plant Species}

Appendix 1 presents a table with details for each species, separately for each plot. The information includes parameters that are assessed in routine forest inventories (mean dbh, trees per ha) as well as the means of the structural parameters Mingling (M), Dominance (D) and Size Differentiation (T). A summary of the details in Appendix 1 is presented in Tab. 2.

Almost 70 percent of all the tree and shrub species encountered in the three study sites occur on all three sites. Thirty one percent,(181-137) of 130, of species are not common to all three sites. 
Table 2. Summary of the species-specific details listed in Appendix 1.

\begin{tabular}{|l|c|c|c|c|}
\hline \multicolumn{1}{|c|}{ Study Site } & $\begin{array}{c}\text { Tree,shrub } \\
\text { \& climber } \\
\text { species }\end{array}$ & $\begin{array}{c}\text { number } \\
\text { of families }\end{array}$ & $\begin{array}{c}\text { species } \\
\text { per family }\end{array}$ & $\begin{array}{c}\text { number of species } \\
\text { introduced/invasive }\end{array}$ \\
\hline Bugarikallu & 76 & 35 & 2.17 & 2 \\
\hline Doresanipalya & 46 & 20 & 2.3 & 10 \\
\hline Thalewoodhouse & 69 & 28 & 2.46 & 1 \\
\hline 3 Sites combined & 130 & 40 & 3.25 & 11 \\
\hline
\end{tabular}

Climbers are plants that are rooted in the ground but use other plants for support. The climbers that were identified in the three permanent study areas were classified based on the mode of climbing as twiners, lianas and stragglers. Lianas are long stemmed woody plants that use the support of a tree moving up to the canopy in search of sunlight. Twiners (or stem climbers) are "twining" themselves spirally around a supporting tree. They may reach the canopy, but are mostly restricted to the understorey. Stragglers (ramblers) are plants that do not climb but somehow manage to support themselves by clinging to the trunks, stems, or branches of other plants. Stragglers have specialized organs, such as prickles, spines or thorns that are used for support. Twenty two species of climbers were found in the three permanent study areas. (Tab. 3).

Altogether 356 individual climbing plants belonging to 12 species occur in the Thalewoodhouse study area. Bugarikallu has 350 individual climbers belonging to 15 species while Doresanipalya has 272 climbing individuals belonging to 7 species. The dominant climber species in Thalewoodhouse are Hiptage benghalensis, a liana which is often found in the upper canopies, and two stragglers: Ziæiphus oenoplia and Jasminum angustifolium.

The most frequent climbers in Bugarikallu are three stragglers: Pterolobium hexapetalum, Jasminum angustifolium and Ziriphus oenoplia. The endangered twiner Decalepis hamiltonii (IUCN Red list of Threatened Species) is also found in Bugarikallu. Ziriphus oenoplia is the most frequent climber in Doresanipalya followed by Gymnema sylvestre, a well-known medicinal plant.

\subsubsection{Exotics: Introduced/Invasive Species}

Two non-native woody plant species occur in Bugarikallu (Cassia siamea; Eucalyptus globulus), ten in Doresanipalya (Acacia auriculiformis; Anacardium occidentale; Annona squamosa; Cassia siamea; Cassia spectabilis; Eucalyptus tereticornis; Grevillea robusta; Jacaranda mimosifolia; Leucaena leucocephala; Psidium guajava), and one in 
Thalewoodhouse (Cassia spectabilis). Numerous rare species are found in each of the three study areas. Many rare species are only represented by one individual (refer to Appendix 1 for details).

Table 3. Details of the 22 species of climber found in the three study areas (Thalewoodhouse TW; Bugarikallu BG; Doresanipalya DO).

\begin{tabular}{|l|c|c|c|l|}
\multicolumn{1}{|c|}{ Species } & TW & BG & DO & \multicolumn{1}{c|}{ Characteristics } \\
\hline Acacia concinna & 5 & 10 & 0 & Shrubby straggler with prickles (understorey \& canopy) \\
\hline Argyreia cuneata & 0 & 2 & 1 & Stout climbing shrub (understorey \& canopy) \\
\hline Argyreia sericea & 0 & 0 & 8 & Stout Climber (on the ground, understorey \& canopy) \\
\hline Cansjera rheedei & 0 & 3 & 0 & Climber (canopy \& understorey) \\
\hline Capparis sepiaria & 0 & 3 & 0 & Scandent shrubs with spines (understorey \& canopy) \\
\hline Celastrus paniculatus & 1 & 5 & 0 & Straggling shrub (understorey) \\
\hline Decalepis hamiltonii & 0 & 1 & 0 & Endangered Twining shrub (Rocks, understorey) \\
\hline Embelia viridifolia & 0 & 0 & 1 & Woody climbers (understorey) \\
\hline Gymnema sylvestre & 0 & 4 & 26 & Twining subshrub (understorey \& Canopy) \\
\hline Hiptage benghalensis & 121 & 0 & 0 & Large woody climber-twiner (Upper canopy) \\
\hline Ichnocarpus frutescens & 14 & 0 & 0 & Climber (understorey \& canopy) \\
\hline Ipomoea illustris & 1 & 0 & 0 & Climber (understorey) \\
\hline Jasminum angustifolium & 40 & 88 & 0 & Straggling shrub (understorey) \\
\hline Mimosa rubicaulis & 18 & 0 & 0 & Straggling shrub with prickles (understorey) \\
\hline Pterolobium hexapetalum & 0 & 169 & 0 & Prickly straggler (understorey) \\
\hline Scutia myrtina & 1 & 17 & 24 & Spiny straggling shrub (understorey \& canopy) \\
\hline Secamone emetic & 0 & 1 & 0 & Scandent shrubs (understorey \& canopy) \\
\hline Toddalia asiatica & 2 & 8 & 0 & Straggler with recurved prickles (understorey \& canopy) \\
\hline Tylophora indica & 0 & 0 & 4 & Slender pubescent climber (understorey \& canopy) \\
\hline Ventilago maderaspatana & 11 & 1 & 0 & Woody climbing shrub (Upper canopy) \\
\hline Ziriphus oenoplia & 139 & 37 & 208 & Scandent shrub with thorns (understorey) \\
\hline Ziriphus rugosa & 3 & 1 & 0 & Straggling shrub with spines (understorey) \\
\hline Total individuals (total species) & $\mathbf{3 5 6} \mathbf{( 1 2 )}$ & $\mathbf{3 5 0} \mathbf{( 1 5 )}$ & $\mathbf{2 7 2} \mathbf{( 7 )}$ & \\
\hline
\end{tabular}

\subsection{Quantitative Results}

\subsubsection{Neighborhood-based Results}

Each tree species is characterized by an average diameter at breast height (dbh), a specific contribution to the total density of woody plants, and by a species-specific neighborhood constellation. The relevant details are found in Appendix 1. The variable Mingling obviously assumes a maximum value of 1.0 for all species that occur with only 1 individual, e.g. Acacia leucophloea, Atalantia monophylla, Carmona retusa, Cipadessa baccifera, Decalepis hamiltonii, Phyllanthus indofischeri and several others in Bugarikallu. The mean Minglingvalues are low for species occurring with a high frequency (e.g. 0.45 for Ixora nigricans with 1033 individuals; 0.57 for Anogeissus latifolia with 546 individuals; 0.51 for Pterolobium hexapetalum with 400 individuals; 0.61 for Canthium dicoccum with 208 individuals) in Bugarikallu. Species occurring with a high relative frequency are likely to have more conspecific neighbors. Premna tomentosa and Shorea roxburghii in Bugarikallu, or Glochidion zeylanicum in Thale have low mingling values despite their low frequencies. Such unexpected constellations indicate spatial aggregation within conspecific clusters. 


\subsubsection{Cell-based Results}

The absolute discrepancies among the three study areas, based on the seven cell variables, are presented in Tab. 4.

Table 4. Absolute discrepancies among the three study areas, based on the seven cell variables that were used in this study.

\begin{tabular}{|l|c|c|c|}
\hline \multicolumn{1}{|c|}{ Variable } & Bugari_Thale & Bugari_Doresan & Doresan_Thale \\
\hline BA_ha & 0.64 & 0.52 & 0.60 \\
\hline N_ha & 0.52 & 0.36 & 0.32 \\
\hline Richness & 0.32 & 0.76 & 0.60 \\
\hline Clark_Evans & 0.08 & 0.48 & 0.44 \\
\hline Dq & 0.68 & 0.48 & 0.48 \\
\hline CVD & 0.84 & 0.76 & 0.68 \\
\hline Mingling & 0.36 & 0.28 & 0.64 \\
\hline
\end{tabular}

Bugarikallu and Thalewoodhouse differ most in density (BA_ha), quadratic mean dbh (Dq) and diameter coefficient of variation (CVD). Bugarikallu and Doresanipalya differ in terms of species richness and diameter coefficient of variation. Doresanipalya and Thalewoodhouse differ most by density, richness, diameter coefficient of variation and cell mingling.

\subsubsection{The Species-Area Relation}

The estimated parameters a and b of the Monod model, and the graphs of the fitted functions for each field plot, are presented in Tab. 5 .

Table 5. Estimated parameters $a$ and $b$ of the Monod model for the three study areas.

\begin{tabular}{|l|c|c|c|}
\hline \multirow{2}{*}{ Study Area } & Species & \multicolumn{2}{c|}{ SAR (Monod) } \\
\cline { 3 - 4 } & Richness & $\mathbf{a}$ & $\mathbf{b}$ \\
\hline Doresanipalya & 46 & 0.04146 & 0.000816 \\
\hline Bugarikallu & 76 & 0.11790 & 0.001513 \\
\hline Thalewoodhouse & 69 & 0.02996 & 0.000449 \\
\hline
\end{tabular}

By solving the Monod equation for any arbitrary area, an estimate of species richness for that area is obtained. The parameters in Tab. 5 can thus be used to make species richness values comparable among different plot sizes.

\subsubsection{The Species Abundance Distribution}

Species abundance curves provide information about how communities differ in the way they are organized. The species abundance distribution generally takes a curve shape that is defined by many rare species and a few common ones (McGill et al., 2007; Matthews and Whittaker, 2014). Fig. 4 presents the three graphs of the fitted SAD's. 


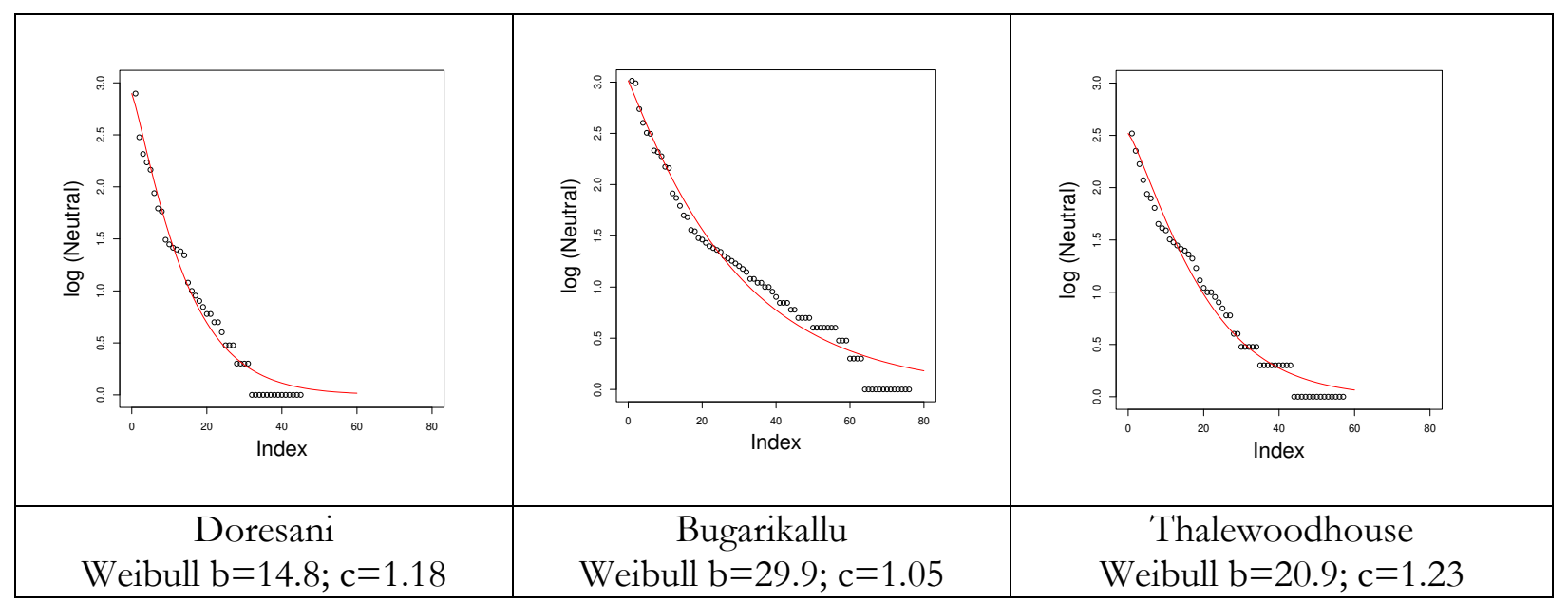

Figure 4. Species Abundance Distributions of the three study areas. When plotted in this way, relative species abundances from very different data sets show similar patterns.

The Weibull parameter $b$ increases with increasing number of species, and can be estimated by the following linear function: Weibull $b=-0.5862+0.3942 *$ (number of species per ha).

The shape of the species abundance distribution is influenced by the degree to which common species dominate the community, and by the number of very rare species (McGlinn et al. 2019). Communities that are strongly dominated by one or a few species often have low species diversity overall. Our results confirm this observation.

\section{Discussion}

A large proportion of the world's population relies directly on forests for livelihood. Sustaining these ecosystems is thus often a matter of survival. Humans have to accept the premise that the allegorical "Garden of Eden" is a dreamworld. Human impact on our planet is so overwhelming that the current period in the Earth's history has been named Anthropocene - the age of humans. Crutzen (2002) concluded that mankind has been and will remain a major environmental force in the future. In this study, we present some examples of evaluating the biology, density and structure of complex forest ecosystems. These methods are part of a scientific toolbox that enables us to make value judgments, and to choose between alternative courses of action.

Planted forests attracted much interest during the 1960's and 1970's of the past century, our study areas are self-regenerating forests. Self-regenerating forests are a vast resource. They include complex primary forests as well as exploited and degraded ecosystems, forests subject to sophisticated selection management systems, or communities dominated by invasive species. New initiatives are required to establish particular 
research infrastructures, and develop new analytical tools to improve our understanding of the biology, structure and dynamics of these complex ecosystems.

\subsection{Tree Species Richness and Diversity}

In community ecology there has been more attention paid to the measurement of species diversity than to almost any other parameter. Accordingly, there is a rich literature on diversity, with many contradictory recommendations (Hubálek, 2000). Most popular are Hill's numbers as easily interpreted measures of diversity. This includes the exponential form of the Shannon ${ }^{2}$ function (Hill's N1) and the reciprocal of Simpson's index (Hill's N2). The choice depends on whether more weight is given to the rare species (N1) or to the common species (N2).

Traditional indices of biodiversity incorporate only the numbers of species and their frequencies without considering the biological differences among the species. Ganeshaiah et al. (1997) proposed a measure of community diversity known as the "Avalanche index". The Avalanche measure, recently "revived" by Hao et al. (2019), is defined as follows:

$$
A=\sum_{i=1}^{S} \sum_{j=i+1}^{S} p_{i} * d_{i j} * p_{j}
$$

where $S$ is the total number of tree species, $p_{i}$ and $p_{j}$ are the relative frequencies of species $i$ and $j$ in the community, and $\mathrm{d}_{\mathrm{ij}}$ is a measure of the taxonomic distance between species $\mathrm{i}$ and $\mathrm{j}$. The Avalanche diversity does not only account for the number of species and their frequencies, but also considers the taxonomic hierarchy. The Shannon entropy would be the same for two communities A and B if both have the same number of species occurring with the same frequencies. The Avalanche diversity in B would exceed that in $\mathrm{A}$ if the number of genera would be greater in $\mathrm{B}$ than in $\mathrm{A}$, because the Avalanche index captures the intracommunity biological variation. The Avalanche is not only useful as an index of diversity, but also as a measure that can be used to assess the dissimilarity of two forest communities (Hao et al., 2019; see also Talents et al., 2005). Tab. 6 shows that the Hill D1 (the exponent of the Shannon index) is almost identical for Bugarikallu and Thalewoodhouse although Bugarikallu has more species than Thalewoodhouse but a lower evenness. This result is supported by the fact that the Avalanche index for Thalewoodhouse exceeds

\footnotetext{
${ }^{2}$ This index is sometimes called "Shannon-Wiener" and sometimes "Shannon-Weaver" Index. The names Wiener and Weaver are similar (sometimes Wiener is spelt incorrectly as Weiner). We follow Spellerberg and Fedor (2003) by referring simply to the "Shannon Index".
} 
that for Bugarikallu. The number of species per family is 2.17 in Bugarikallu, and 2.46 in Thalewoodhouse (Tab. 2) which explains the slightly greater Avalanche value for Thalewoodhouse.

Table 6. Species richness per ba and three measures of diversity: the Shannon entropy and its exponent value, Hill number D1, and the Avalanche index for the three plots.

\begin{tabular}{|l|c|c|c|c|}
\hline \multicolumn{1}{|c|}{ Study Area } & $\begin{array}{c}\text { TreeShrub, \& Climber Species } \\
\text { Richness }\end{array}$ & Shannon & Hill D1 & Avalanche \\
\hline Doresanpalya & 46 & 2.263 & 9.61 & 0.321 \\
\hline Bugarikallu & 76 & 3.078 & 21.71 & 0.345 \\
\hline Thalewoodhouse & 69 & 3.069 & 21.52 & 0.352 \\
\hline
\end{tabular}

Species richness depends on plot size. One way to derive a common estimate of species richness, is to develop a species-area relation (SAR) for each plot individually, and to estimate richness for a particular standard area, such as 1 hectare. The results from this study thus provide a useful basis for comparison with other ecosystems, and for testing general assumptions presented in previous studies (e.g. Preston, 1962; May, 1975; Hubbell, 2001).

A quantity of considerable practical relevance is the minimum contiguous area required to capture all the species within a particular region. Gadow and Hui (2007) found a relationship, based on tree-mapped field plots assessed in various regions of the world, between the maximum number of tree species within a forest region $\left(S_{\max }\right.$, which is often known), and the minimum contiguous area required to capture all the species within that region $\left(A_{\text {min }}\right.$, measured in $\mathrm{m}^{2}$ ). The minimum contiguous area was estimated in their

study by the function $A_{\min }=487.8 \times S_{\max }^{0.524}$. This result implies that, for contiguous forest areas, the form of the species-area relationship is directly defined by the observed species abundance and the maximum number of species in the region. Assuming that the maximum number of species in the region around Bengaluru is 130 , the estimate of the minimum contiguous area to capture all species would be $487.8^{*} 130^{\wedge} 0.524=6250.98 \mathrm{~m}^{2}$ in each of the three plots. This area is less than that of the study areas $\left(10000 \mathrm{~m}^{2}\right)$, but inspection of the graphs of the SAR functions reveals that the estimate is quite reasonable.

\subsection{Specific Relationships}

The relationships between variables that are often assessed in routine forest inventories (mean dbh and number of trees), and neighborhood parameters (Mingling and Dominance) are shown in Fig. 5 for the three study areas. The relation between the number of trees per ha and the mean neighborhood mingling is estimated using a power function. The relation between the mean $\mathrm{dbh}(\mathrm{cm})$ and the mean neighborhood 
Dominance is estimated using the Monod function. Figure 5 presents the graphs and the equations of these relationships for each study area.

\begin{tabular}{|c|c|c|c|}
\hline & Bugarikallu & Doresanipalya & Thalewoodhouse \\
\hline \multirow[t]{2}{*}{$\begin{array}{l}\text { relativefrequency } \\
\text { vs neighborhood } \\
\text { mingling,all } \\
\text { species }\end{array}$} & (c) & (1) & : \\
\hline & $\mathrm{M}=\exp \left(-2.53 * \mathrm{~N}^{0.30}\right)$ & $\mathrm{M}=\exp \left(-1.12^{*} \mathrm{~N}^{0.46}\right)$ & $\mathrm{M}=\exp \left(-1.85^{*} \mathrm{~N}^{0.55}\right)$ \\
\hline \multirow[t]{2}{*}{$\begin{array}{l}\text { mean dbh vs } \\
\text { neighborhood } \\
\text { dominance,all } \\
\text { species }\end{array}$} & - & 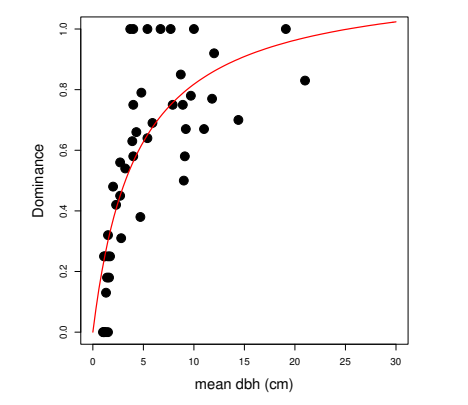 & (1) \\
\hline & $\mathrm{D}=0.28^{*} \mathrm{x} /\left(1+0.26^{*} \mathrm{x}\right)$ & $\mathrm{D}=0.27 * \mathrm{dbh} /(1+0.23 * \mathrm{dbh})$ & $\mathrm{D}=0.034^{*} \mathrm{x} /\left(1+0.35^{*} \mathrm{x}\right)$ \\
\hline
\end{tabular}

Figure 5. The relationships between species-specific variables in the three plots. Shown are the number of trees per ha and the mean neighborhood mingling with the estimated non-linear model below (upper row); the mean dbh (cm) and the mean neighborhood Dominance with the estimated Monod model (below).

The structural parameters provide additional information about the close-range neighborhood of each species. Not surprisingly, high correlation values are found between tree density and mingling for individual species. No relation was found regarding the dbh differentiation $(\mathrm{T})$. Tree size variation within neighborhood groups was independent of tree size and the degree of species mingling.

\subsection{Conclusions}

Forests include a great variety of ecosystems where plants and animals interact with their physical environment. The challenge is to sustain their ability to function, to adapt to changing climates, and to satisfy a variety of human needs. Permanent field plots with mapped trees provide an essential "green infrastructure" for observing the dynamic evolution of such ecosystems. This study presents three 
examples of tropical dry forests in South India with details of the biological and fine-scale structural characteristics of the 130 woody plant species. The Weibull model was used to characterize the species abundance distribution. Non-linear relationships were established between close-range neighborhood structure, species abundance and relative dominance. A previously published general assumption for estimating the minimum contiguous area required to capture all species based on regional species richness was confirmed.

\section{Declarations}

\subsection{Ethics approval and consent to participate}

Not applicable

\subsection{Consent for publication}

Not applicable

\subsection{Availability of data and material}

The datasets used and/or analysed during the current study are available from the corresponding author on request.

\subsection{Competing interest}

The authors declare that they have no competing interests.

\subsection{Funding}

The financial support was provided by the Department of Science \& Technology (DST), Government of India under the Stragetic Programs, Large Initiatives and Coordinated Action Enabler (SPLICE) project.

\subsection{Authors contributions}

All authors contributed equally; KVG analyzed and interpreted the data. All authors read \& approved the final manuscript. 


\subsection{Acknowledgements}

We thank the Karnataka Forest Department (KFD) for giving us permission to establish the permanent preservation plot (PPP) in Bannerghatta National Park (BNP) and also providing us help/manpower during our studies in this elephant prone area. We are indebted to all the BNP forest watchers for accompanying us during field visits. Our heartfelt thanks are due to Ms Saswathi Misra, Ex Director, EMPRI for assistance in initiating the project works, Mr Dattaraja, IISc and Mr Kiranraddi, EMPRI for the helps in establishing the plots in forests. We also thank Mr. Suresh, , Forest Survey of India (FSI) \& Mr. Abhilash, , National Institute of Hydrology for the preparation of maps of forest types and study area. The support provided by researchers in the Centre for Climate Change, EMPRI is also gratefully acknowledged .

\section{References}

Aguirre O, Hui GY, Gadow KV, Jimenez J (2003) Comparative analysis of natural forest sites in Durango, Mexico. Forest Ecology and Management 183:137-145.

Alekseev, Alexander, Erkki Tomppo, Ronald E. McRoberts and Klaus v. Gadow (2019) A constructive review of the State Forest Inventory in the Russian Federation. Forest Ecosystems 2019:6.

Borchert, R. (1994) Water storage in soil or tree stems determines phenology and distribution of tropical dry forest trees. Ecology 75:1437-1449.

Bray JR and Curtis JT (1957) An ordination of the upland forest communities of southern Wisconsin. Ecological monographs 27(4):325-349.

Champion HG, Seth SK (1968) A Revised Survey of the Forest Types of India. Govt. of India Press, Delhi, 404 p

Clarke KR, Warwick RM (1998) A taxonomic distinctness index and its statistical properties. Journal of applied ecology 35(4):523-531.

Clarke KR, Warwick RM (2001) A further biodiversity index applicable to species lists: variation in taxonomic distinctness. Marine Ecology Progress Series 216:265-278.

Condit, R. (2008) Methods for estimating above-ground biomass of forest and replacement vegetation in the tropics. Center for Tropical Forest Science Research Manual, 73 pages.

de Caprariis P., Lindemann R.H., Collins, C.M. (1976) A method for determining optimum sample size in species diversity studies. Mathematical Geology 8(5): 575-581.

Dunstan PK, Bax NJ, Foster SD, Williams A, Althaus F (2012). Identifying hotspots for biodiversity management using rankabundance distribution. Diversity and Distributions, 18: 22-32.

Gadow K.v. (1993) Zur Bestandesbeschreibung in der Forsteinrichtung (engl: How to describe a forest). Forst und Holz 48(21):602-606

Gadow, K. v., Hui, G. Y (2007) Can the tree species-area relationship be derived from prior knowledge of the tree species richness? Forestry Studies / Metsanduslikud Uurimused 46: 13-22.

Gadow, K. v., Xiu Hai Zhao, V. P. Tewari, Chun Yu Zhang, Ashwani Kumar, Jose Javier Corral Rivas and Rajesh Kumar (2016) Forest observational studies: an alternative to designed experiments. European Journal of Forest Research 135(3): 417-431.

Ganeshaiah KN, Chandrashekara K, and Kumar ARV (1997) Avalanche index: a new measure of biodiversity based on biological heterogeneity of the communities. Current Science 73(2):128-133. 
Ganeshaiah KN, and Shaanker RU (2000) Measuring biological heterogeneity of forest vegetation types: avalanche index as an estimate of biological diversity. Biodiversity \& Conservation 9(7):953-963.

Gitay, H., Rexburg, S.H.,Wilson, J. B. (1991) Species-Area relation in a New Zealand tussock grassland, with implications for nature reserve design and for community structure. J. Veg. Sci. 2:113-118.

Hao, Minhui; J. Javier Corral-Rivas; M. Socorro González-Elizondo; K. Narayanagowda Ganeshaiah; M. Guadalupe NavaMiranda; Chunyu Zhang, Xiuhai Zhao and Klaus von Gadow (2019) Assessing biological dissimilarities between five forest communities. Forest Ecosystems 2019, 6:30.

Hao, Minhui; Kotiganahalli Narayanagowda Ganeshaiah, Chunyu Zhang, Xiuhai Zhao, Klaus von Gadow (2019) Discriminating among forest communities based on taxonomic, phylogenetic and trait distances. Forest Ecology and Management 440, 2019, 40-47

Hayden, B., and Greene, D.F. (2008) The ecology of tropical dry forests. A chapter in the Encyclopedia of Tropical Ecology and Conservation (UNESCO).

Hubálek, Zdenûk (2000) Measures of species diversity in ecology: an evaluation. Folia Zool. - 49(4): 241-260.

Hubbell, S. P (2001) The unified Neutral Theory of Biodiversity and Biogeography. Princeton University Press. Princeton u. Oxford: $375 \mathrm{p}$.

Hubbell, S. P (2001) The unified Neutral Theory of Biodiversity and Biogeography. Princeton University Press. Princeton u. Oxford: 375 p.

Hui, Cang and DM Richardson (2017) Invasion Dynamics. Oxford University Press: 322 p.

Hui, G.Y., Albert, M, Gadow, K. v. (1998) Das Umgebungsmaß als Parameter zur Nachbildung von Bestandesstrukturen [Dominance as a measure of Forest Structure]. Forstwissenschaftliches Centralblatt 117(1): 258-266.

Kleinschmit, D; Stephanie Mansourian, Christoph Wildburger and Andre Purret (eds.) (2016) Illegal Logging and Related Timber Trade - Dimensions, Drivers, Impacts and Responses. A Global Scienti c Rapid Response Assessment Report. IUFRO World Series Volume 35.Vienna. 148 p.

Komonen A, Elo M (2017) Ecological response hides behind the species abundance distribution: community response to lowintensity disturbance in managed grasslands. Ecology \& Evolution, 7(20): 8558-8566.

Lawton, J. H. (1999) Are there general laws in ecology? Oikos 84:177-192.

Marris, E. (2013) Perspective: Coming of Age in a Trash Forest. In: Hobbs et al. 2013, Wiley-Blackwell, Chapter 29: 245

Matthews TJ, Borges PAV, Whittaker RJ (2014) Multimodal species abundance distributions: a deconstruction approach reveals the processes behind the pattern. Oikos, 123: 533-544.

Matthews, T. J., and Whittaker, R. J. (2014) Fitting and comparing competing models of the species abundance distribution: assessment and prospect. Frontiers of Biogeography, 6(2), 67-82.

McGill BJ, Etienne RS, Gray JS, Alonso D, AndersonMJ, Benecha HK, Dornelas M, Enquist BJ, Green JL, He FL, Huilbert AH, Magurran AE, Marquet PA, Maurer BA, Ostling A, Soykan CU, Ugland KI, White EP (2007) Species abundance distributions: moving beyond single prediction theories to integration within an ecological framework. Ecology Letters 10: 995-1015.

McGlinn DJ, Xiao X, May F, Daniel J. McGlinn Xiao Xiao Felix May Gotelli NJ, Engel T, Blowes SA, Knight TM, Purschke O, Chase JM, McGill BJ (2019) Measurement of Biodiversity (MoB): A method to separate the scale-dependent effects of species abundance distribution, density, and aggregation on diversity change. Methods in Ecology and Evolution 10: 258269.

Miles, L., A. C. Newton, R. S. DeFries, C. Ravilious, I. May, S. Blyth, V. Kapos, and J. E. Gordon (2006) A global overview of the conservation status of tropical dry forests. Journal of Biogeography 33:491-505.

Monod, J (1950) La technique de culture continue, the'orie et applications. Annales de l'Institut Pasteur 79: 390-410.

Pommerening, A. and Grabarnik, P (2019) Individual-based Methods in Forest Ecology and Management. Springer Nature: 411 p. 
Pommerening, A., Wang, H. \& Zhao, Z. (2020) Global woodland structure from local interactions: new nearest-neighbour functions for understanding the ontogenesis of global forest structure. Forest Ecosystems 7, 22, 2020 https://doi.org/10.1186/s40663-020-00224-5

Richardson, D.M., Cang Hui, Martin A. Nuñez, Anibal Pauchard (2014) Tree invasions - patterns, processes, challenges and opportunities. Biol. Invasions Vol 16: 473-481. DOI 10.1007/s10530-013-0606-9.

Kakkar.R., K. H. Vinaya Kumar, O.K. Remadevi, M. Manjunatha, B. Saritha. B. Sharma, M. Kiranraddi H. S.Dattaraja and H. S. Suresh (2018) Establishing permanent preservation plots in Bannerghatta National Park for long-term ecological studies to monitor climate change. My Forest 54: 19-34.

Raju, R. (2014). Master Plan of Bannerghatta Biological Park, Bangalore, 2014-15 to 2033 34, Karnataka Forest Department.

Sagarin R. and Pauchard, A. (2012) Observation and Ecology. Island Press: 213 pp.

Schütz, J.-Ph., Pukkala, T., Donoso, P. and Gadow, K. v. (2012) Historical Emergence and Current Application of CCF. In: T. Pukkala and K. v. Gadow (eds.): Continuous Cover Forestry. Book Series Managing Forest Ecosystems Vol 24, (C) Springer Science+Business Media B.V.: p. 1-28.

Singh, J. S. and R. K. Chaturvedi. (2017a) Diversity of ecosystem types in India: A review. Proceedings of Indian National Science Academy 83: 569 - 594.

Singh, J.S. and R.K Chaturvedi (2017b) Tropical Dry Deciduous Forest: Research Trends and Emerging Features. Springer: 238 pages

Sørensen TA (1948) A method of establishing groups of equal amplitude in plant sociology based on similarity of species content, and its application to analysis of the vegetation on Danish commons. Biologiske Skrifter Kongelige Danske Videnskabernes Selskab 5:1-34.

Spellerberg, Ian, F. and Fedor, Peter, J. (2003) A tribute to Claude Shannon (1916-2001) and a plea for more rigorous use of species richness, species diversity and the 'Shannon-Wiener' Index. Global Ecology \& Biogeography 2003, 12, $177-179$.

Talents LA, Lovett JC, Hall JB, Hamilton AC (2005) Phylogenetic diversity of forest trees in the Usambara mountains of Tanzania: correlations with altitude. Botanical Journal of the Linnean Society 149(2):217-228.

Tjørve, E.( 2003) Shapes and functions of species-area curves: a review of possible models. J. Biogeography 30: $827-835$.

Wehenkel C, Corral-Rivas JJ, and Gadow K.v. (2014) Quantifying differences between ecosystems with particular reference to selection forests in Durango/Mexico. Forest Ecology and Management 316:117-124.

Williams M. R. (1995) An extreme-value function model of the species incidence and species-area relationship. Ecology 76: 2607 -2616 .

Zeng WeiSheng, Erkki Tomppo, Sean P. Healey and Klaus v. Gadow (2015) The national forest inventory in China: history results - international context. Forest Ecosystems, 2:23. 
APPENDIX I: Species tagged in the three permanent preservation plots

\begin{tabular}{|c|c|c|c|c|c|c|c|c|}
\hline \multicolumn{9}{|c|}{ Thalewoodhouse } \\
\hline Species & meand & meanH & $\mathbf{N}$ & BA & $\begin{array}{c}\text { mean } \\
\mathbf{M}\end{array}$ & $\begin{array}{c}\text { mean } \\
\text { D }\end{array}$ & $\begin{array}{c}\text { mean } \\
T\end{array}$ & $\begin{array}{c}\text { mean } \\
\mathrm{CV}\end{array}$ \\
\hline Acacia concinna & 5.8 & 0 & 8 & 0.03 & 0.78 & 0.78 & 0.4 & 0.46 \\
\hline Albizia odoratissima & 37.9 & 13 & 1 & 0.11 & 1 & 1 & 0.9 & 1 \\
\hline Allophylus cobbe & 2.6 & 3.5 & 12 & 0.01 & 0.91 & 0.52 & 0.34 & 0.47 \\
\hline Ardisia solanacea & 2.9 & 2.7 & 134 & 0.11 & 0.4 & 0.45 & 0.38 & 0.55 \\
\hline Baubinia racemosa & 3 & 2 & 2 & 0 & 1 & 0.63 & 0.32 & 0.5 \\
\hline Breynia retusa & 2.2 & 2 & 2 & 0 & 1 & 0.75 & 0.31 & 0.51 \\
\hline Breynia vitis-idaea & 2.1 & 2.5 & 1 & 0 & 1 & 0.5 & 0.47 & 0.63 \\
\hline Butea frondosa & 17.5 & 6 & 1 & 0.02 & 1 & 1 & 0.87 & 1 \\
\hline Canthium dicoccum & 1.8 & 3 & 2 & 0 & 0.75 & 0.38 & 0.31 & 0.48 \\
\hline Canthium parviflorum & 2.6 & 2.8 & 10 & 0.01 & 0.88 & 0.4 & 0.39 & 0.47 \\
\hline Careya arborea & 12.5 & 11 & 3 & 0.04 & 0.83 & 0.92 & 0.73 & 0.97 \\
\hline Cassia fistula & 5.5 & 5.1 & 32 & 0.14 & 0.8 & 0.55 & 0.48 & 0.6 \\
\hline Cassia spectabilis & 6.3 & 6 & 1 & 0 & 1 & 1 & 0.61 & 0.56 \\
\hline Celastrus paniculatus & 1.1 & 0 & 1 & 0 & 1 & 0 & 0.65 & 0.49 \\
\hline Cipadessa baccifera & 1.9 & 2.3 & 404 & 0.13 & 0.34 & 0.47 & 0.32 & 0.45 \\
\hline Cordia wallichii & 9.4 & 6.5 & 31 & 0.26 & 0.94 & 0.89 & 0.64 & 0.78 \\
\hline Dalbergia lanceolaria & 21.6 & 15.2 & 8 & 0.49 & 0.91 & 0.78 & 0.74 & 0.85 \\
\hline Dendrocalamus strictus & 2.5 & 2.5 & 3 & 0 & 0.83 & 0.5 & 0.4 & 0.47 \\
\hline Dimocarpus longan & 1.5 & 1.5 & 1 & 0 & 1 & 0 & 0.4 & 0.26 \\
\hline Diospyros melanoxylon & 8.8 & 4.1 & 4 & 0.03 & 1 & 0.63 & 0.34 & 0.38 \\
\hline Diospyros montana & 6.8 & 6 & 17 & 0.1 & 0.97 & 0.67 & 0.49 & 0.69 \\
\hline Embelia tsjeriam-cottam & 2.1 & 1.9 & 8 & 0 & 0.34 & 0.41 & 0.37 & 0.6 \\
\hline Ervatamia beyneana & 1.5 & 1.5 & 1 & 0 & 1 & 0 & 0.55 & 0.86 \\
\hline Erythrina stricta & 11.1 & 8 & 1 & 0.01 & 1 & 1 & 0.69 & 0.85 \\
\hline Erythroxylum monogynum & 2 & 2.9 & 4 & 0 & 0.88 & 0.13 & 0.59 & 0.88 \\
\hline Ficus microcarpa & 50.3 & 25 & 10 & 3.6 & 0.03 & 0.6 & 0.59 & 0.99 \\
\hline Flueggea leucopyrus & 1.6 & 2 & 1 & 0 & 1 & 0 & 0.64 & 0.65 \\
\hline Garuga pinnata & 1.6 & 2 & 1 & 0 & 1 & 0 & 0.49 & 1 \\
\hline Glochidion velutinum & 6.1 & 5.9 & 119 & 0.52 & 0.37 & 0.51 & 0.43 & 0.63 \\
\hline Glochidion zeylanicum & 5.2 & 3.7 & 31 & 0.14 & 0.48 & 0.58 & 0.47 & 0.62 \\
\hline Gmelina arborea & 18.3 & 14 & 2 & 0.06 & 1 & 0.88 & 0.53 & 0.61 \\
\hline Grewia tiliifolia & 1.6 & 2 & 1 & 0 & 1 & 0.25 & 0.28 & 0.31 \\
\hline Helicteres isora & 2.2 & 3.3 & 4 & 0 & 0.75 & 0.56 & 0.35 & 0.34 \\
\hline Hiptage benghalensis & 5.3 & 0 & 183 & 0.61 & 0.69 & 0.55 & 0.46 & 0.64 \\
\hline Holarrhena antidysenterica & 3.8 & 2.3 & 2 & 0 & 1 & 0.25 & 0.38 & 0.58 \\
\hline Ichnocarpus frutescens & 2.4 & 0 & 19 & 0.02 & 0.83 & 0.22 & 0.5 & 0.76 \\
\hline Ipomoea illustris & 1.8 & 0 & 1 & 0 & 1 & 0.75 & 0.17 & 0.15 \\
\hline Ixora nigricans & 2.8 & 2.8 & 151 & 0.12 & 0.74 & 0.48 & 0.44 & 0.63 \\
\hline Jasminum angustifolium & 2.3 & 0 & 46 & 0.02 & 0.95 & 0.29 & 0.45 & 0.61 \\
\hline Mallotus philippensis & 4.8 & 4.4 & 26 & 0.1 & 0.45 & 0.52 & 0.46 & 0.74 \\
\hline Maytenus emarginata & 2.2 & 1.5 & 2 & 0 & 0.75 & 0.75 & 0.32 & 0.8 \\
\hline Memecylon umbellatum & 3.1 & 4.4 & 7 & 0.01 & 0.5 & 0.64 & 0.42 & 0.54 \\
\hline
\end{tabular}




\begin{tabular}{|l|c|c|c|c|c|c|c|c|} 
Miliusa tomentosa & 6 & 5.1 & 6 & 0.03 & 0.67 & 0.75 & 0.54 & 0.73 \\
\hline Mimosa rubicaulis & 2.5 & 0 & 31 & 0.02 & 0.73 & 0.42 & 0.33 & 0.43 \\
\hline Mitragyna parvifolia & 12.5 & 10.1 & 9 & 0.18 & 0.31 & 0.61 & 0.58 & 0.82 \\
\hline Olea dioica & 4.9 & 4.5 & 517 & 2.19 & 0.55 & 0.52 & 0.42 & 0.57 \\
\hline Pavetta indica & 2 & 2.9 & 16 & 0.01 & 0.77 & 0.27 & 0.49 & 0.59 \\
\hline Phyllanthus emblica & 6.5 & 5.6 & 8 & 0.06 & 0.93 & 0.64 & 0.46 & 0.54 \\
\hline Phyllanthus polyphyllus & 3 & 3.8 & 479 & 0.48 & 0.29 & 0.53 & 0.35 & 0.45 \\
\hline Phyllanthus reticulatus & 4.6 & 2.7 & 5 & 0.01 & 0.75 & 0.55 & 0.41 & 0.84 \\
\hline Polyalthia cerasoides & 3 & 2.8 & 91 & 0.13 & 0.84 & 0.45 & 0.41 & 0.58 \\
\hline Polyaltbia coffeoides & 5.3 & 4.2 & 10 & 0.04 & 0.89 & 0.61 & 0.57 & 0.85 \\
\hline Premna tomentosa & 15.7 & 6 & 6 & 0.18 & 0.38 & 0.71 & 0.55 & 0.75 \\
\hline Pterocarpus marsupium & 37.2 & 17.7 & 3 & 0.39 & 1 & 1 & 0.81 & 0.85 \\
\hline Randia dumetorum & 4.8 & 4.5 & 93 & 0.26 & 0.59 & 0.63 & 0.45 & 0.6 \\
\hline Schleichera oleosa & 8.8 & 6.4 & 13 & 0.14 & 0.75 & 0.67 & 0.59 & 0.76 \\
\hline Scutia myrtina & 2.3 & 0 & 3 & 0 & 0.5 & 0.42 & 0.51 & 0.69 \\
\hline Shorea roxburgbii & 9.3 & 8 & 20 & 0.26 & 0.79 & 0.58 & 0.52 & 0.74 \\
\hline Sysygium cumini & 20.1 & 10.6 & 50 & 3.62 & 0.75 & 0.73 & 0.63 & 0.83 \\
\hline Tarenna asiatica & 1.9 & 1.5 & 1 & 0 & 1 & 0.5 & 0.27 & 0.48 \\
\hline Terminalia arjuna & 45.1 & 15.5 & 42 & 9.36 & 0.67 & 0.8 & 0.71 & 0.88 \\
\hline Terminalia bellirica & 38.9 & 15.3 & 46 & 7.2 & 0.87 & 0.92 & 0.74 & 0.89 \\
\hline Terminalia chebula & 2.9 & 16 & 1 & 0 & 1 & 0.75 & 0.3 & 0.3 \\
\hline Toddalia asiatica & 2 & 0 & 3 & 0 & 0.83 & 0.25 & 0.46 & 0.65 \\
\hline Ventilago madraspatana & 5.5 & 0 & 17 & 0.06 & 0.88 & 0.46 & 0.47 & 0.58 \\
\hline Vitex altissima & 6.6 & 7.2 & 11 & 0.06 & 0.91 & 0.41 & 0.65 & 0.82 \\
\hline Wrigbtia tinctoria & 4.1 & 4 & 2 & 0 & 1 & 1 & 0.46 & 0.38 \\
\hline Ziziphus oenoplia & 3 & 0 & 281 & 0.25 & 0.57 & 0.53 & 0.37 & 0.47 \\
\hline Ziziphus rugosa & 2.1 & 0 & 4 & 0 & 0.88 & 0.19 & 0.59 & 0.85 \\
\hline
\end{tabular}

\begin{tabular}{|l|c|c|c|c|c|c|c|c|}
\hline \multicolumn{9}{|c|}{ Bugarikallu } \\
\hline Species & meanD & meanH & N & BA & $\begin{array}{c}\text { mean } \\
\text { M }\end{array}$ & $\begin{array}{c}\text { mean } \\
\text { D }\end{array}$ & $\begin{array}{c}\text { mean } \\
\text { T }\end{array}$ & $\begin{array}{c}\text { mean } \\
\text { CV }\end{array}$ \\
\hline Acacia chundra & 9.31 & 5.25 & 189 & 1.55 & 0.7 & 0.8 & 0.53 & 0.64 \\
\hline Acacia concinna & 2.3 & 0 & 22 & 0.01 & 0.57 & 0.36 & 0.39 & 0.47 \\
\hline Acacia leucopbloea & 9.23 & 6 & 1 & 0.01 & 1 & 1 & 0.7 & 0.79 \\
\hline Albiria amara & 3.49 & 2.57 & 7 & 0.01 & 0.68 & 0.54 & 0.43 & 0.59 \\
\hline Albiria cbinensis & 1.5 & 2 & 5 & 0 & 1 & 0.05 & 0.41 & 0.39 \\
\hline Anogeissus latifolia & 5.87 & 5.45 & 546 & 1.77 & 0.57 & 0.69 & 0.43 & 0.52 \\
\hline Argyreia cuneata & 1.43 & 0 & 3 & 0 & 0.75 & 0.17 & 0.53 & 0.68 \\
\hline Atalantia monophylla & 1.3 & 1 & 1 & 0 & 1 & 0 & 0.46 & 0.33 \\
\hline Baubinia racemosa & 10.24 & 7.57 & 14 & 0.14 & 0.77 & 0.86 & 0.61 & 0.8 \\
\hline Breynia vitis-idaea & 2.39 & 2.94 & 25 & 0.01 & 0.9 & 0.38 & 0.42 & 0.51 \\
\hline Bridelia retusa & 6.83 & 4.75 & 2 & 0.01 & 1 & 0.63 & 0.34 & 0.31 \\
\hline Buchanania axillaris & 9.63 & 4.74 & 17 & 0.15 & 0.82 & 0.82 & 0.51 & 0.6 \\
\hline Cansjera rbeedei & 1.94 & 0 & 5 & 0 & 0.8 & 0.5 & 0.3 & 0.41 \\
\hline Cantbium dicoccum & 4.12 & 4.11 & 208 & 0.4 & 0.61 & 0.56 & 0.44 & 0.54 \\
\hline Canthium parviflorum & 2.42 & 2.58 & 36 & 0.02 & 0.6 & 0.38 & 0.39 & 0.53 \\
\hline Capparis sepiaria & 5.93 & 0 & 4 & 0.01 & 0.88 & 0.75 & 0.51 & 0.66 \\
\hline Carmona retusa & 1.5 & 1.5 & 1 & 0 & 1 & 0.75 & 0.13 & 0.16 \\
\hline Cassia fistula & 3.44 & 3 & 29 & 0.03 & 0.79 & 0.52 & 0.43 & 0.49 \\
\hline
\end{tabular}




\begin{tabular}{|c|c|c|c|c|c|c|c|c|}
\hline Cassia montana & 1.18 & 2.4 & 5 & 0 & 1 & 0.05 & 0.66 & 0.84 \\
\hline Cassia siamea & 11.88 & 5.5 & 22 & 0.39 & 0.56 & 0.69 & 0.47 & 0.61 \\
\hline Cassine glauca & 7.86 & 5.75 & 10 & 0.05 & 0.55 & 0.78 & 0.46 & 0.56 \\
\hline Celastrus paniculatus & 3.45 & 0 & 7 & 0.01 & 0.93 & 0.21 & 0.61 & 0.54 \\
\hline Cipadessa baccifera & 1.5 & 2 & 1 & 0 & 1 & 0 & 0.68 & 1 \\
\hline Dalbergia lanceolaria & 6.59 & 5.79 & 17 & 0.09 & 0.76 & 0.79 & 0.54 & 0.66 \\
\hline Decalepis hamiltonii & 1.7 & 0 & 1 & 0 & 1 & 0.25 & 0.6 & 0.75 \\
\hline Dendrocalamus strictus & 1.81 & 2.59 & 149 & 0.04 & 0.11 & 0.9 & 0.07 & 0.15 \\
\hline Diospyros melanoxylon & 6.22 & 4.43 & 74 & 0.3 & 0.78 & 0.7 & 0.48 & 0.59 \\
\hline Diospyros montana & 5.37 & 3.64 & 7 & 0.03 & 0.93 & 0.57 & 0.51 & 0.59 \\
\hline Dodonaea viscosa & 1.54 & 2.16 & 29 & 0.01 & 0.76 & 0.31 & 0.34 & 0.5 \\
\hline Erythroxylum monogynum & 3.21 & 3.32 & 975 & 0.97 & 0.38 & 0.53 & 0.34 & 0.42 \\
\hline Eucalyptus globulus & 5.97 & 12 & 4 & 0.02 & 0.25 & 0.44 & 0.5 & 0.73 \\
\hline Ficus benghalensis & 27.71 & 10 & 11 & 0.72 & 0.14 & 0.57 & 0.33 & 0.4 \\
\hline Ficus microcarpa & 91.99 & 9 & 1 & 0.66 & 1 & 1 & 0.94 & 1 \\
\hline Flacourtia indica & 3.24 & 2.95 & 50 & 0.06 & 0.79 & 0.46 & 0.42 & 0.55 \\
\hline Flueggea leucopyrus & 3.8 & 4 & 1 & 0 & 1 & 0.75 & 0.35 & 0.44 \\
\hline Gardenia turgida & 1.1 & 1.5 & 1 & 0 & 1 & 0.25 & 0.22 & 0.33 \\
\hline Grenia asiatica & 6.76 & 6 & 2 & 0.01 & 0.75 & 0.88 & 0.5 & 0.61 \\
\hline Grewia birsuta & 1.1 & 1.5 & 1 & 0 & 1 & 0 & 0.69 & 0.48 \\
\hline Grewia orbiculata & 3.06 & 2.84 & 82 & 0.08 & 0.69 & 0.44 & 0.42 & 0.51 \\
\hline Gymnema sylvestre & 1.78 & 0 & 4 & 0 & 1 & 0.31 & 0.32 & 0.47 \\
\hline $\begin{array}{l}\text { Holarrbena } \\
\text { antidysenterica }\end{array}$ & 3.12 & 3.11 & 49 & 0.05 & 0.67 & 0.58 & 0.42 & 0.52 \\
\hline Ixora nigricans & 3.2 & 3.07 & 1033 & 1.02 & 0.45 & 0.53 & 0.35 & 0.43 \\
\hline Jasminum angustifolium & 1.7 & 0 & 145 & 0.04 & 0.83 & 0.27 & 0.43 & 0.57 \\
\hline Lagerstroemia parviflora & 6.34 & 4.75 & 20 & 0.08 & 0.65 & 0.7 & 0.4 & 0.49 \\
\hline Madbuca indica & 7.46 & 5.87 & 19 & 0.14 & 0.39 & 0.62 & 0.4 & 0.47 \\
\hline Maytenus emarginata & 2.23 & 2.29 & 319 & 0.15 & 0.48 & 0.43 & 0.37 & 0.5 \\
\hline Memecylon umbellatum & 2.46 & 5 & 11 & 0.01 & 0.41 & 0.48 & 0.42 & 0.52 \\
\hline Naringi crenulata & 5.34 & 4.5 & 4 & 0.01 & 0.94 & 0.88 & 0.51 & 0.67 \\
\hline Ocbna obtusata & 3.74 & 3.23 & 215 & 0.27 & 0.61 & 0.52 & 0.37 & 0.45 \\
\hline Phyllanthus indofischeri & 11.62 & 7 & 1 & 0.01 & 1 & 1 & 0.75 & 0.88 \\
\hline Polyalthia cerasoides & 3.81 & 3.86 & 18 & 0.03 & 0.97 & 0.57 & 0.47 & 0.56 \\
\hline Polyalthia coffeoides & 2.55 & 2.88 & 4 & 0 & 0.69 & 0.5 & 0.51 & 0.56 \\
\hline Premna tomentosa & 3.06 & 3.22 & 25 & 0.02 & 0.39 & 0.5 & 0.39 & 0.4 \\
\hline Pterocarpus marsupium & 9.5 & 6.06 & 8 & 0.07 & 1 & 0.84 & 0.71 & 0.91 \\
\hline Pterolobium hexapetalum & 2.08 & 0.01 & 400 & 0.17 & 0.51 & 0.43 & 0.34 & 0.47 \\
\hline Randia dumetorum & 2.45 & 2.26 & 27 & 0.02 & 0.61 & 0.34 & 0.41 & 0.49 \\
\hline Rapanea wigbtiana & 7.32 & 5 & 2 & 0.01 & 0.75 & 0.88 & 0.35 & 0.33 \\
\hline Santalum album & 2.56 & 3.67 & 3 & 0 & 1 & 0.17 & 0.4 & 0.62 \\
\hline Scolopia crenata & 5.09 & 6 & 1 & 0 & 1 & 0.75 & 0.35 & 0.45 \\
\hline Scutia myrtina & 2.14 & 0 & 35 & 0.02 & 0.72 & 0.39 & 0.39 & 0.49 \\
\hline Secamone emetica & 1.5 & 0 & 1 & 0 & 1 & 0 & 0.39 & 0.41 \\
\hline Semecarpus anacardium & 13.53 & 6.75 & 6 & 0.09 & 0.75 & 0.88 & 0.59 & 0.79 \\
\hline Shorea roxburghii & 5.06 & 5.5 & 12 & 0.03 & 0.33 & 0.63 & 0.44 & 0.49 \\
\hline Soymida febrifuga & 8.65 & 5.75 & 2 & 0.01 & 1 & 1 & 0.57 & 0.72 \\
\hline Stereospermum suaveolens & 8.06 & 6.63 & 4 & 0.03 & 0.88 & 0.69 & 0.6 & 0.67 \\
\hline Strychnos potatorum & 6.44 & 3.78 & 9 & 0.04 & 0.89 & 0.56 & 0.53 & 0.63 \\
\hline
\end{tabular}




\begin{tabular}{|l|c|c|c|c|c|c|c|c|} 
Tarenna asiatica & 1.77 & 2.62 & 313 & 0.09 & 0.56 & 0.33 & 0.39 & 0.53 \\
\hline Terminalia chebula & 9.44 & 6.97 & 15 & 0.11 & 0.72 & 0.8 & 0.56 & 0.7 \\
\hline Terminalia paniculata & 8.52 & 5.5 & 4 & 0.03 & 1 & 0.81 & 0.62 & 0.73 \\
\hline Toddalia asiatica & 1.63 & 0 & 10 & 0 & 0.95 & 0.23 & 0.42 & 0.46 \\
\hline Ventilago maderaspatana & 3.7 & 0 & 5 & 0.01 & 0.75 & 0.8 & 0.33 & 0.52 \\
\hline Vitex altissima & 5.19 & 6.33 & 12 & 0.03 & 0.67 & 0.65 & 0.46 & 0.59 \\
\hline Wrigbtia tinctoria & 6.65 & 7.5 & 6 & 0.05 & 0.13 & 0.75 & 0.55 & 1 \\
\hline Ziziphus oenopolia & 2.19 & 0.29 & 62 & 0.03 & 0.71 & 0.35 & 0.43 & 0.56 \\
\hline Ziziphus rugosa & 2.9 & 0 & 1 & 0 & 1 & 0 & 0.36 & 0.22 \\
\hline Ziziphus xylopyrus & 2.4 & 3.5 & 4 & 0 & 0.88 & 0.5 & 0.49 & 0.41 \\
\hline
\end{tabular}

\begin{tabular}{|l|c|c|c|c|c|c|c|c|}
\hline \multicolumn{7}{|c|}{ Doresanipalya } \\
\hline Species & meanD & meanH & N & BA & $\begin{array}{c}\text { mean } \\
\text { M }\end{array}$ & $\begin{array}{c}\text { mean } \\
\text { D }\end{array}$ & $\begin{array}{c}\text { mean } \\
\text { T }\end{array}$ & $\begin{array}{c}\text { mean } \\
\text { CV }\end{array}$ \\
\hline Acacia auriculiformis & 9.5 & 7.4 & 117 & 1.32 & 0.55 & 0.66 & 0.56 & 0.73 \\
\hline Albiria amara & 6 & 8 & 2 & 0.01 & 0.75 & 0.5 & 0.63 & 0.83 \\
\hline Albiria lebbeck & 11.2 & 5.4 & 33 & 0.54 & 0.85 & 0.77 & 0.6 & 0.78 \\
\hline Albiria odoratissima & 4 & 3.5 & 1 & 0 & 1 & 0.75 & 0.32 & 0.34 \\
\hline Anacardium occidentale & 5.2 & 2.8 & 23 & 0.08 & 0.12 & 0.58 & 0.41 & 0.52 \\
\hline Annona squamosa & 1.1 & 2.5 & 1 & 0 & 1 & 0 & 0.31 & 0.32 \\
\hline Argyreia cuneata & 1.2 & 0 & 1 & 0 & 1 & 0.25 & 0.48 & 0.98 \\
\hline Argyreia sericea & 1.2 & 0 & 11 & 0 & 0.91 & 0.2 & 0.45 & 0.73 \\
\hline Bambusa bambos & 4.9 & 9.3 & 398 & 0.8 & 0 & 1 & 0 & 0 \\
\hline Breynia vitis-idaea & 1.4 & 2.4 & 79 & 0.01 & 0.64 & 0.43 & 0.27 & 0.41 \\
\hline Cantbium parviflorum & 1.3 & 1.8 & 3 & 0 & 0.83 & 0.25 & 0.49 & 1 \\
\hline Cassia fistula & 4.9 & 3.1 & 7 & 0.03 & 0.58 & 0.67 & 0.34 & 0.5 \\
\hline Cassia siamea & 17.4 & 9.9 & 9 & 0.22 & 0.42 & 0.67 & 0.45 & 0.51 \\
\hline Cassia spectabilis & 3.4 & 5 & 27 & 0.03 & 0.47 & 0.54 & 0.38 & 0.49 \\
\hline Cassine paniculata & 7.1 & 4.3 & 4 & 0.02 & 0.88 & 0.81 & 0.53 & 0.58 \\
\hline Dendrocalamus strictus & 2.9 & 3.4 & 794 & 0.53 & 0.1 & 0.94 & 0.06 & 0.14 \\
\hline Diospyros melanoxylon & 3.4 & 2.6 & 29 & 0.04 & 0.73 & 0.59 & 0.39 & 0.53 \\
\hline Embelia viridifolia & 1.1 & 0 & 1 & 0 & 0.75 & 0.25 & 0.4 & 0.73 \\
\hline Erytbroxylum monogynum & 2.3 & 2.7 & 45 & 0.02 & 0.58 & 0.54 & 0.35 & 0.43 \\
\hline Eucalyptus tereticornis & 13.7 & 10.8 & 220 & 4.86 & 0.54 & 0.69 & 0.6 & 0.8 \\
\hline Flacourtia indica & 1.5 & 1.5 & 1 & 0 & 1 & 0.25 & 0.37 & 0.44 \\
\hline Flueggea leucopyrus & 2.1 & 2.7 & 25 & 0.01 & 0.51 & 0.55 & 0.23 & 0.26 \\
\hline Grevillea robusta & 12 & 7.2 & 3 & 0.05 & 1 & 0.92 & 0.64 & 0.77 \\
\hline Gymnema sylvestris & 1.4 & 0 & 30 & 0 & 0.9 & 0.2 & 0.43 & 0.56 \\
\hline Homalium zeylanicum & 8.9 & 6 & 1 & 0.01 & 1 & 1 & 0.76 & 0.89 \\
\hline Ixora bracbiata & 1.3 & 1.5 & 1 & 0 & 1 & 0 & 0.66 & 0.76 \\
\hline Ixora nigricans & 1.1 & 1.5 & 1 & 0 & 1 & 0.25 & 0.56 & 1 \\
\hline Jacaranda mimosifolia & 3.9 & 6 & 2 & 0 & 0.75 & 0.88 & 0.4 & 0.45 \\
\hline Lannea coromandelica & 4.6 & 3.4 & 9 & 0.02 & 0.84 & 0.81 & 0.5 & 0.62 \\
\hline
\end{tabular}




\begin{tabular}{|l|c|c|c|c|c|c|c|c|} 
Leucaena leucocephala & 2.5 & 4.1 & 43 & 0.06 & 0.63 & 0.37 & 0.37 & 0.4 \\
\hline Mallotus philippensis & 1 & 2 & 1 & 0 & 1 & 0 & 0.35 & 0.5 \\
\hline Ochna obtusata & 4.2 & 2.8 & 9 & 0.02 & 0.78 & 0.69 & 0.31 & 0.33 \\
\hline Pongamia pinnata & 5.5 & 5.5 & 12 & 0.06 & 0.73 & 0.56 & 0.48 & 0.73 \\
\hline Psidium guajava & 3.5 & 2.5 & 2 & 0 & 0.75 & 0.88 & 0.38 & 0.4 \\
\hline Pterocarpus marsupium & 4.8 & 4.4 & 72 & 0.23 & 0.72 & 0.61 & 0.5 & 0.67 \\
\hline Santalum album & 2.1 & 3.4 & 1388 & 0.57 & 0.37 & 0.45 & 0.36 & 0.5 \\
\hline Scutia myrtina & 1.6 & 0 & 27 & 0.01 & 0.92 & 0.19 & 0.46 & 0.59 \\
\hline Shorea roxburghii & 8.4 & 4.9 & 398 & 3.91 & 0.59 & 0.68 & 0.47 & 0.61 \\
\hline Syzygium cumini & 6.4 & 5.7 & 3 & 0.01 & 0.83 & 0.33 & 0.44 & 0.66 \\
\hline Tamarindus indica & 8.3 & 5.7 & 13 & 0.1 & 0.81 & 0.71 & 0.54 & 0.71 \\
\hline Terminalia arjuna & 6.7 & 4 & 1 & 0 & 1 & 1 & 0.82 & 1 \\
\hline Terminalia chebula & 5.4 & 4.5 & 1 & 0 & 1 & 1 & 0.68 & 0.74 \\
\hline Terminalia paniculata & 19.1 & 11 & 1 & 0.03 & 1 & 1 & 0.89 & 1 \\
\hline Tylophora indica & 1.3 & 0 & 5 & 0 & 0.9 & 0.15 & 0.4 & 0.5 \\
\hline Ziziphus mauritiana & 6.4 & 4.5 & 6 & 0.02 & 0.75 & 0.88 & 0.59 & 0.68 \\
\hline Ziziphus oenoplia & 2.7 & 0 & 505 & 0.38 & 0.35 & 0.53 & 0.36 & 0.48 \\
\hline
\end{tabular}




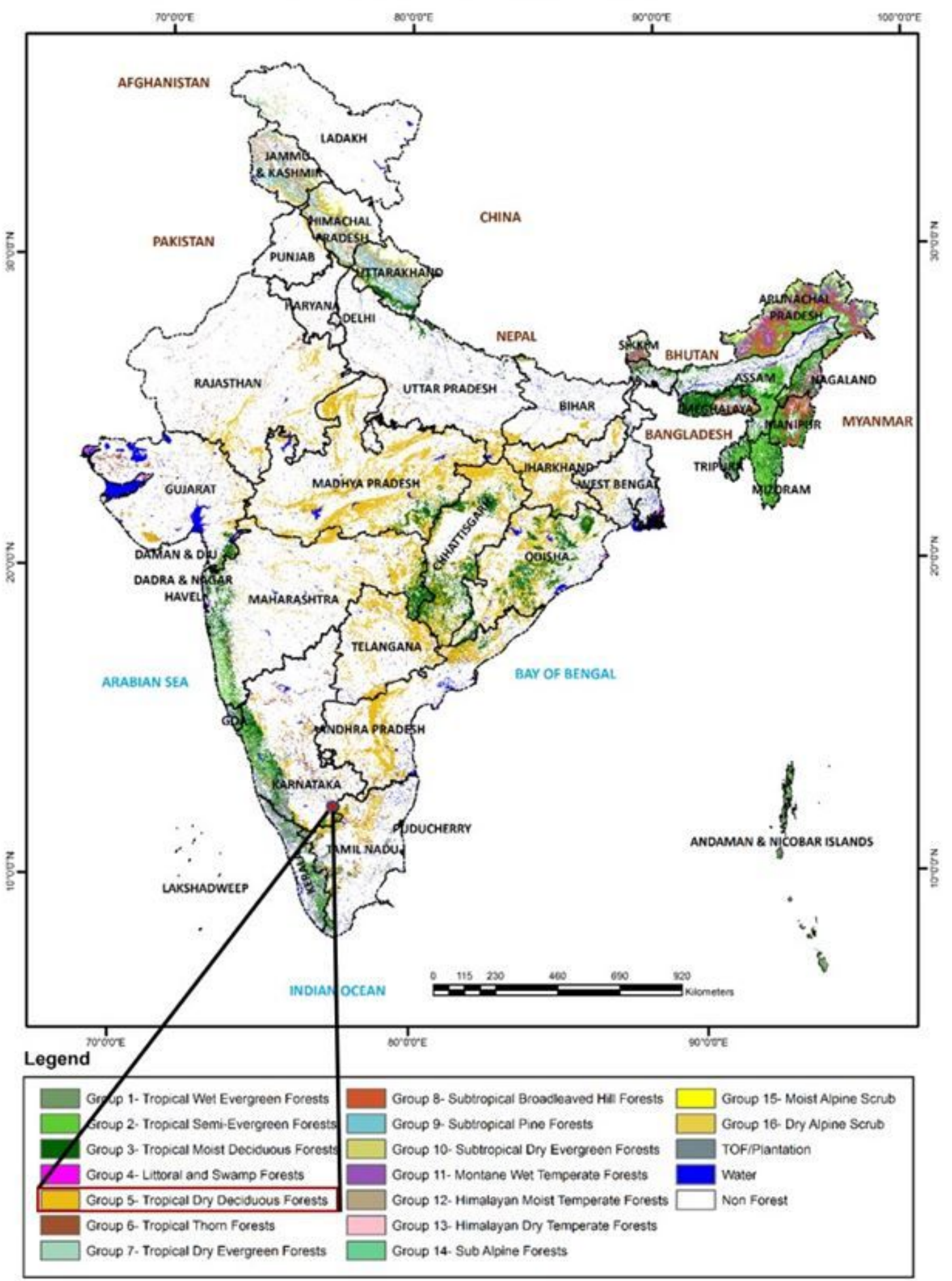

\section{Figure 1}

Distribution of forest types in India (map kindly provided by the Forest Survey of India, 2019). The study areas are located in the vicinity of Bengaluru in the South-Eastern part of the State of Karnataka. 


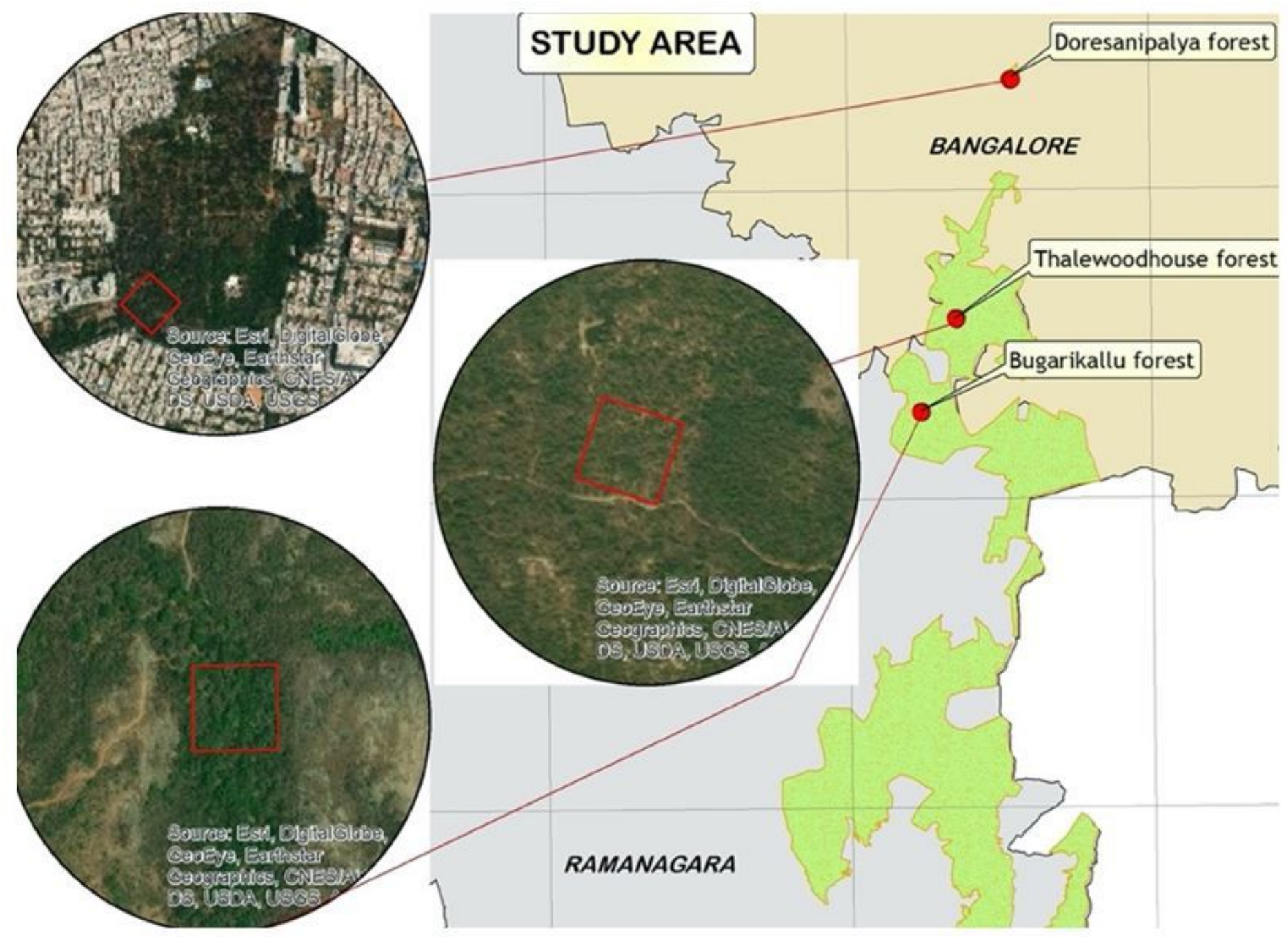

Figure 2

Location of the three study sites to the south of the Bengaluru city center. Google map images of the study sites and their immediate surroundings are shown in the three circles. 


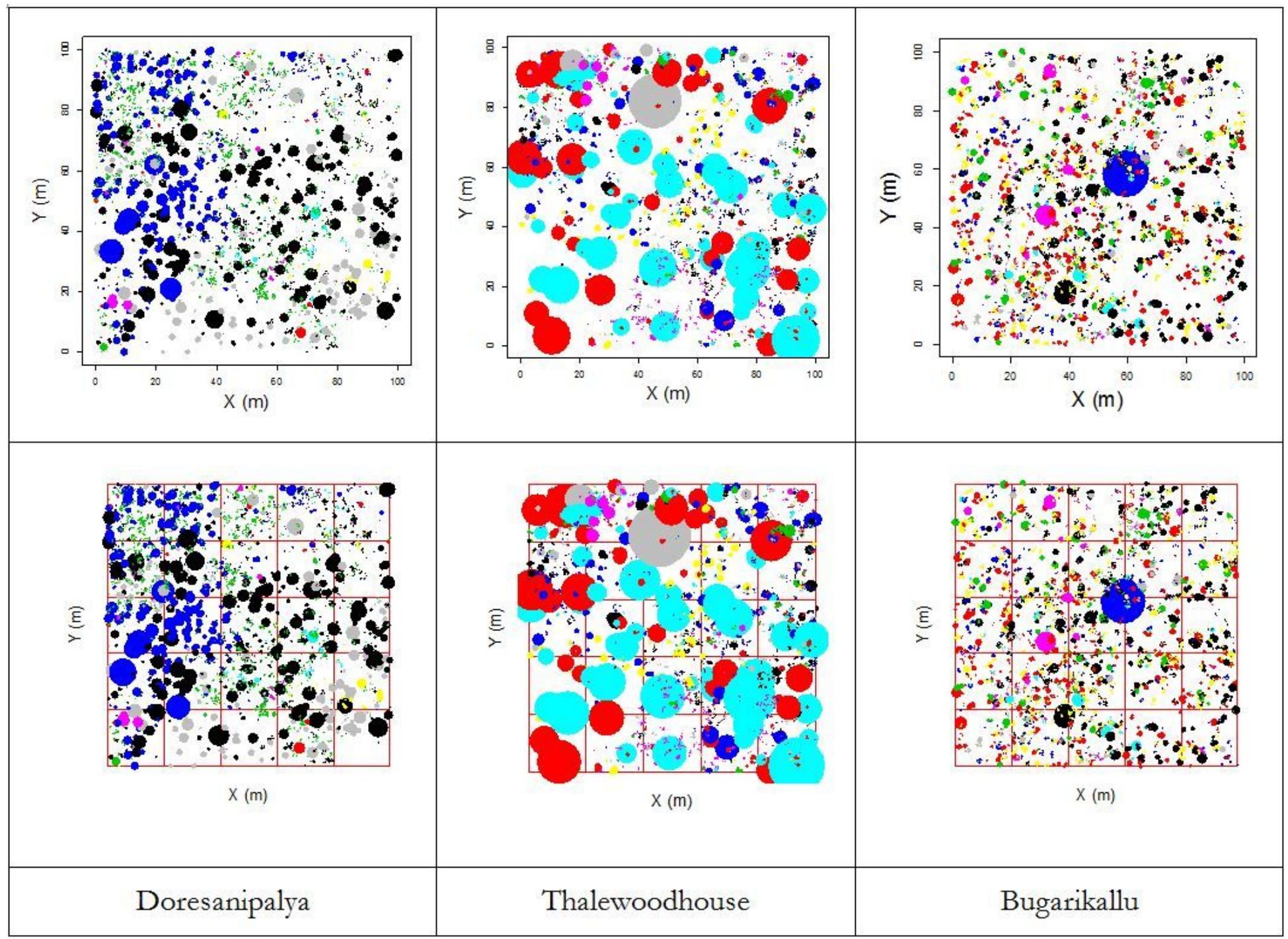

Figure 3

A general impression of the spatial species mix and tree size distribution in the three study areas. Each species has a unique color across all three study sites. The subdivision into smaller cells facilitates analysis of the spatial distribution (and scale dependence) of particular patterns. 


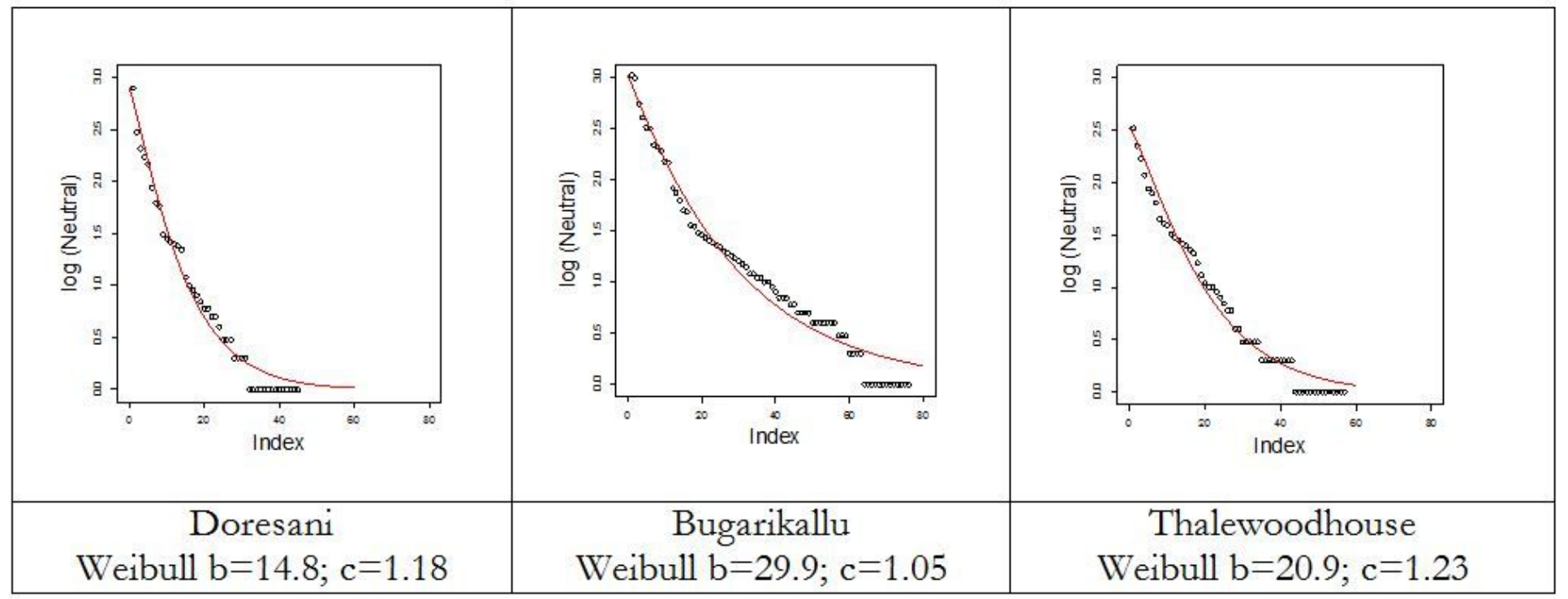

Figure 4

Species Abundance Distributions of the three study areas. When plotted in this way, relative species abundances from very different data sets show similar patterns.

\begin{tabular}{|c|c|c|c|}
\hline & Bugarikallu & Doresanipalya & Thalewoodhouse \\
\hline \multirow[t]{2}{*}{$\begin{array}{l}\text { relativefrequency } \\
\text { vs neighborhood } \\
\text { mingling,all } \\
\text { species }\end{array}$} & (1) & 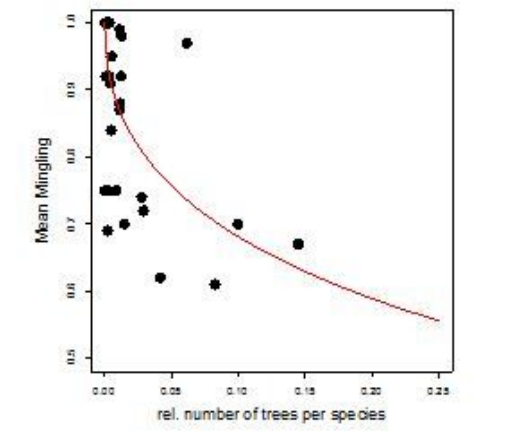 & (1) \\
\hline & $\mathrm{M}=\exp \left(-2.53 * \mathrm{~N}^{0.30}\right)$ & $\mathrm{M}=\exp \left(-1.12 * \mathrm{~N}^{0.46}\right)$ & $\mathrm{M}=\exp \left(-1.85 * \mathrm{~N}^{0.55}\right)$ \\
\hline \multirow[t]{2}{*}{$\begin{array}{l}\text { mean dbh vs } \\
\text { neighborhood } \\
\text { dominance,all } \\
\text { species }\end{array}$} & $=$ & : & 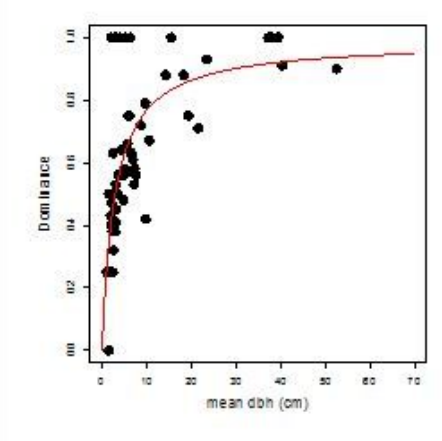 \\
\hline & $\mathrm{D}=0.28^{*} \mathrm{x} /\left(1+0.26^{*} \mathrm{x}\right)$ & $\mathrm{D}=0.27 * \mathrm{dbh} /(1+0.23 * \mathrm{dbh})$ & $\mathrm{D}=0.034^{*} \mathrm{x} /\left(1+0.35^{*} \mathrm{x}\right)$ \\
\hline
\end{tabular}


The relationships between species-specific variables in the three plots. Shown are the number of trees per ha and the mean neighborhood mingling with the estimated non-linear model below (upper row); the mean $\mathrm{dbh}(\mathrm{cm})$ and the mean neighborhood Dominance with the estimated Monod model (below). 